\title{
Agribusiness innovation: A pathway to sustainable economic growth in Africa
}

by Ademola, A., Manning, L. and Azadi, $H$.

Copyright, Publisher and Additional Information: This is the author accepted manuscript. The final published version (version of record) is available online via Elsevier Please refer to any applicable terms of use of the publisher.

DOI: http://dx.doi.org/10.1016/j.tifs.2016.11.008 


\section{Agribusiness innovation: a pathway to sustainable economic growth in Africa}

Ademola A. Adenle ${ }^{12}$, Louise Manning ${ }^{34}$, Hossein Azadi ${ }^{5}$

1 School of Global Environmental Sustainability, Colorado State University, USA

2 United Nations University-Institute of Advanced Studies of Sustainability (UNU-IAS), Japan

3 School of Agriculture, Food and Environment, Royal Agriculture University, UK

4 School of Food Science and Agri-food Supply Chain Management, Harper Adams University, UK

5Department of Geography, Ghent University, Belgium

Corresponding Author

\section{Ademola A. Adenle ${ }^{12}$}

108 Johnson Dr, Fort Collins,

CO 80523, United States

Tel: +1 970-492-4215

Email: adenle.ademola@ colostate.edu;aadenle@gmail.com

Acknowledgement

Special thanks to Prof. Blessing M. Muambe and Prof. Alan Renwick for constructive comments and correction of earlier version of the manuscript.

\section{Abstract}


The paper considers the factors that drive a strong and competitive agri-business sector with particular attention to investment in research and development (R\&D) for technological innovation as well as the broader drivers and risk factors of influence. It develops a case study and in particular contrasts the very successful value chain in Thailand with the weak one in Nigeria in order to highlight the implications for Nigerian government policy if it wishes to exploit the potential for a strong cassava agri-business sector.

Keywords: Science and technology, Agribusiness, Key drivers, Risk factors, Economic growth, Africa

\section{Introduction}

Given the rising African population, there is an urgent need to refocus the continent's agricultural development strategies toward promoting rapid and sustainable economic growth, food security and poverty reduction. This debate is being led by international organizations including the World Bank, United Nations Industrial Development Organization (UNIDO) and Food and Agriculture Organization of the United Nations (FAO). According to a World Bank report, the potential for African agribusiness is huge in the light of untapped water resources and with 45 percent of the world's uncultivated agricultural land being within the African continent (Byerlee, Garcia, Giertz, \& Palmade, 2013). The report also argued that harnessing agribusiness opportunities was critical in order to feed the region's fast-growing urban population, potentially resulting in a trillion dollar food market by the year 2030. However, in order to deliver this goal, low levels of agricultural productivity as well as access to infrastructure and technological innovation must be addressed to fully reap the economic benefits. It is therefore fundamental to 
first recognize and then address these barriers on the pathway to achieving sustainable economic growth. The competitiveness of the agribusiness sector in Africa is critical to the socio-economic sustainability of the region as the informal agribusiness sector is responsible for the great majority of job creation (Yumkella, Kormawa, Reopstorff, \& Hawkins, 2011). Although empirical literature is yet to fully establish a causal link between growth in the agribusiness sector and long-term socio-economic sustainability, such development can play an important role in economic development (World Bank, 2008).

A key to agribusiness' growth in many industrialized countries, both in terms of success domestically and internationally, has been attributed to the factors that drive the increasing competitiveness of the sector. For example, many countries in Asia and Latin America have enjoyed the big advantages of infrastructure, innovation, and trade liberalization, thus increasing agricultural productivity which then cascades into a strong contribution to gross domestic product (GDP) (Wilkinson \& Rocha, 2009; World Bank, 2008). This paper, using case study examples, provides insights into the key drivers and risk factors in Africa, using Nigeria as the case study country, that influence agribusiness development and competitiveness in domestic, regional and international markets. The business model developed will emphasize how the drivers/risk factors facilitate or impede agribusiness development in Africa. Furthermore, through a comparison between Sub-Saharan Africa (SSA), Asia and the Pacific, the major role of the private sector in rural development and agricultural and agro-processing investment in developing countries will be highlighted. The countries of Nigeria and Thailand will be used to reflect on how enabling factors contribute to the competitiveness of agribusiness in the domestic and global cassava industry. The rationale for choosing the cassava industry is that it is under-exploited in Africa and has great potential for driving agribusiness development. The countries were chosen in this study 
because Nigeria is the largest producer of cassava in the world albeit with a fragmented industry structure, and Thailand is the largest cassava exporter in the world, thus providing a suitable focus for comparative analysis. A literature review has been conducted as well as an in-depth analysis of private sector investments in agribusiness development in SSA and the Asia-Pacific, followed by an analysis of the two case studies.

\section{The context: agribusiness development in Africa}

African agribusiness is an informal sector, primarily containing small agro-enterprises that are uncoordinated and scattered between localized rural markets. Developing a feasible and active African agribusiness sector is not only a development concern, but also a market opportunity for companies and specifically smallholders who are the biggest private agriculture investors in Africa (EC, 2013). Agribusiness provides major linkages and motivates investors in a way that may not only have significant multiplier impacts on growth, both also address food insecurity by enhancing productivity and increasing wealth for small-scale farmers and rural societies. Targeted agribusiness investment can promote agricultural value chains by providing direct inputs such as standard seeds, irrigation systems, appropriate fertilizers, and enhance post-harvest infrastructure, for instance transport and refrigeration systems. Value can also be added by means of adopting certification schemes and branding, and developing infrastructure thereby assisting small-scale farmers to address quality and safety rules affording opportunity for those producers that are usually are excluded from international markets. Therefore, agribusiness can have a major multiplier effect on development if the correct policy framework is developed and adopted (EC, 2013). Agribusiness investment activity by multinational corporations is localized in a few African countries, for example, the top 20 agribusiness companies ranked on turnover are located 
in South Africa ( $n=10)$, Morocco (3) Nigeria (3) Ivory Coast (2) Algeria (1) and Egypt (1) (Ibrahim Forum, 2011). In addition, there are a few other emerging private firms engaged in supermarket business through contract farming in the horticultural sector in countries including Ghana, Kenya, Ivory Coast and Zimbabwe (Colin, 2013; Voisard \& Jaeger, 2003; Weinberger \& Lumpkin, 2007). The benefits of contract farming, in particular, include the provision of farm inputs, profitability modeling, exchange of information and the integration of smallholders into a cohesive supply chain (Weinberger \& Lumpkin, 2007). However, controversy surrounding the motivations of large private organizations including concerns over land grabbing and in reality limited integration from national into global markets undermines many contracting farming operations in Africa. Whilst high value non-traditional agricultural products such as flowers, and processed fresh fruits and vegetables prove important for the horticultural export sector thus stimulating market growth through the value chain, there is yet to be any obvious impact or improvement in overall performance of the totality of agribusiness on the African continent. In the light of a rapidly growing population, African countries, particularly in SSA, continue to depend on agriculture as the source of their livelihood and economic growth. The African population is expected to reach 2.2 billion by the year 2050 and half of the population will be living in cities resulting in major changes in demand for agricultural and food products, and ultimately improving the prospects for agribusiness (UNDESA, 2010). External drivers such as national or regional policy also play a part. An attempt to transform African agriculture through Structural Adjustment Programs has barely yielded meaningful results among smallholders as it lacks the coherent strategies to enhance agricultural development (Poole, Chitundu, \& Msoni, 2013) 
Since the 1960s, agriculture's share of GDP and the proportion of the labor force involved in agriculture has declined respectively from $21 \%$ to $17 \%$ and $83 \%$ to $64 \%$ in Africa (BinswangerMkhize, McCalla, \& Patel, 2010). The GDP ratio of the level of integrated agribusiness models to pure primary agriculture is important. As the agribusiness share of total GDP becomes higher per capita income increases (World Bank, 2008). According to Wilkinson and Rocha, 2009, agribusiness contributes thirteen times more to GDP than pure agriculture in the United States (US), while in South Africa this ratio is 4:1. Therefore the agribusiness/agriculture ratio defines the sophistication of the sector and also how it impacts on the livelihood assets of citizens. Further the agribusiness/agriculture ratio encompasses important factors contributing to agrobased value chains including innovation, marketing, supply, processing, transportation and distribution of agricultural products. A case study based on eight countries: Cameroon, Ethiopia, Kenya, Nigeria, Senegal, South Africa, Zambia and Mali highlights that food and beverages was the most dominant player in the agro-industry sector over the past four decades, compared to other agro-crops such as tobacco, leather, rubber and wood and paper and the pattern is similar too in terms of job creation between 1998 and 2008 (Kormawa, Wohlmuth, \& Devlin, 2011).

In Nigeria, despite a range of approaches, agricultural improvement has been moderate (Oluwatoyese, Applanaidu, \& Razak, 2016). These approaches have included: policy encouragement of mechanized large scale farming, food security initiatives and credit schemes such as the Agriculture Credit Scheme (ACS), but any benefits have been offset by economic weakness leading to mass unemployment, inflation, a disequilibrium in balance of payments and a shortage of raw materials (Oluwatoyese, et al., 2016). The success or failure of agribusiness in South Africa and other African countries can be attributed to a series of underlying drivers and risks factors and these are now explored. 


\section{Factors underlying agribusiness competitiveness in developing countries- analyzing opportunities and challenges in Africa}

In view of the fragmented nature of agribusiness/agro-industries as previously described a number of key drivers and risk factors could facilitate or conversely impede the development of agribusiness generally in Africa. The benefits of drivers or specific risks may vary across different countries in Africa especially in terms of how they influence agribusiness development but as more data become available in the future, further refinements should allow more detailed analysis of how each factor shapes or limits agribusiness development in the region. The drivers are introduced using case studies from other developing economies.

Past experience from Asia (China, India) and Latin America (Brazil) links infrastructure improvement, and agricultural research and development to the transition toward agroindustrialization and economic growth that actually impacts on food security and poverty reduction (Reardon \& Barrett, 2000; Reardon, Barrett, Berdegue, \& Swinnen, 2009; Wilkinson \& Rocha, 2009). Investment in rural infrastructure has a major positive impact on agricultural production and trade, where, government, domestic and international donors have invested in the rural development of roads and transport pathways (Jouanjean, 2013). Jalan and Ravallion (2002) conclude that road density was one of the significant driving forces for Chinese household's expectation for tackling poverty in a way that for every $1 \%$ raise in the distance of roads per capita in rural regions in China, household consumption increased by $0.08 \%$ (Jalan \& Ravallion, 2002). Fan and Chan-Kang (2005) conducted a cost-benefit analysis for GDP of investment in rural roads with low quality comparing to high-quality roads, revealing that in China, there is no significant correlation between high-quality roads and agricultural GDP whereas low-quality 
roads produce 1.57 yuan of agricultural GDP for every invested yuan. In rural areas of India, Fan et al. (2000) also found that public investment in rural roads had the most positive effect on the growth of agricultural productivity (Fan, Hazell, \& Thorat, 2000), thus demonstrating that investment in rural transport infrastructure is crucial for business growth.

By the 1990s, Brazil was experiencing an agricultural boom which was mainly based on a rapidly growing modern agribusiness sector and the growing trend of the Brazilian agribusiness (Abbey, Baer, \& Filizzola, 2005). This growth was characterized by investment in agricultural research e.g. the expansion of technologies into an area with infertile soils in the Brazilian Central West region and improved accessibility to agricultural credit, which led to in substantial productivity achievements compared with the 1970s. The average annual growth rate of total factor productivity in the agriculture sector in Brazil was calculated at 3.3\% and 5.7\% over the period 1975-2002 and 1998 and 2002, respectively, which were considerably more than the growth rate of $1.8 \%$ in the US agricultural business sector during the period 1948 and 2002 (Chaddad \& Jank, 2006). This rapid growth in Brazil was also attributed to the change in agricultural institutions, policy and attitude that transformed the sector from a traditional economic system to a dynamic agribusiness sector. More recently in Brazil, two inconsistent power factors have developed: firstly agribusiness groups, along with their emerging modern agricultural technology generating fast rates of growth; and alternatively programs such as Movimentos dos Trabalhadores sem Terra (MST), that consider broader equity in the diversity of land and its production (Abbey, et al., 2005).

Growth was observed in China, when in 1978 a range of fundamental market related reforms in the rural community were introduced. However, there are disagreements between researchers 
about the main reasons behind the significant agriculture growth from 1979 onwards that was observed. The reforms included: increased crop prices, changes from a collective system to individual household based farming systems, and government reforms in policy related issues. Agribusiness development, underpinned by higher agricultural production, was crucial in the acceleration of growth in these regions. Indeed, in order for significant productivity gains to happen, agricultural development and growth needs to be underpinned by both technology and investment. Over the past 20 years, increases in government investment in agriculture in East and South Asia have been linked to fast agricultural growth and the move towards agribusiness development and the achieving of the Millennium Development Goals (UNEP, 2005). According to Swinnen and Van Herck, 2010 and Reardon et al. 2009, the restructuring of each agriculture industry segment towards dynamic agribusiness has resulted from three series of driving forces: (1) policy interventions such as public investments, market and trade liberalization and foreign direct investment (FDI); (2) demand side determinants such as increasing incomes, urbanization and decrease in transaction costs for consumers as a result of availability of more infrastructures like refrigerators, roads, and vehicles; and (3) FDI and competitive local investments derived by entrepreneurs in agro-food industry which were looking for scope, specialization and scale economies. Therefore, the African continent will need similar strategic models to be implemented in order to enhance agribusiness development and ultimately provide economic growth.

\subsection{Drivers}

\subsubsection{Financial services and macroeconomic environment}

Financial services institutions will play a significant role in terms of resource mobilization to develop and sustain agribusiness in Africa. However, the lack of reliable financial-service 
institutions, and weak business linkages to global financial systems and capital markets pose a major threat to agribusiness investors. In fact, access to finance has been identified as the greatest barrier to doing business in the region (Schwab, 2013). There is a dearth of recent information on the financial risk and constraints that may be associated with agribusiness in Africa. However, a 2010 study by the USAID analyzed data on the relationship between agribusiness and basic financial services in SSA (Pelrine, Besigye, \& Schuster, 2010). This study emphasizes the importance of financial services as a catalyst for agribusiness development in the rural areas, and also highlights some of the constraints affecting financial services regarding agribusiness. With regard to East Africa (including Kenya, Uganda and Tanzania), financial institutions are often reluctant to lend money to smallholder farmers because of the lack of both transparent record keeping and sufficient collateral.

The uncertainty of inflation, investment returns and unreliable cash flows also proves to be a barrier (Zhang, Rockmore, \& Chamberlin, 2007). For example, in 2007, the inflation rate in Egypt and Sudan was $9.3 \%$ and $8.0 \%$, respectively and in 2011, the inflation rates in East African countries (Uganda, Kenya, Burundi, Tanzania and Ethiopia) almost reached 20\% (IMF, 2014). From 2007-2010 in SSA, the average inflation rate was 9.1\%, compared with $5.5 \%$ in developing Asia and 1.5\% in the advanced economies (IMF, 2010). Pelrine et al., (2010) argue that high levels of inflation can influence the cost of financial services and create uncertainty in the economy. This raises the operating costs of investors that are ultimately then passed on to the borrowers. The importance of macroeconomics and how it affects agribusiness development in Africa cannot be overemphasized. Macroeconomic instability underpinned by poor institutional quality (such as weak governance), interest rates, exchange rates (see Oluwatoyese et al. 2016), 
capital flows, investment and exchange-rate policies are some of the most important macroeconomic aspects that affect the potential of agribusiness development in Africa.

The most important source of fiscal revenue, tax, remains a key economic component of macroeconomic regulation. However, Africa's tax administration is very inefficient and weak (Carter \& Cebreiro, 2011; OECD, 2011b). In 2010, OECD countries' tax revenues account for more than a third of GDP, but they account for less than a fifth of GDP in SSA. The weak tax revenue system has been cited as a key constraint to investment and productivity in Africa. Moreover, the underlying challenges include: poorly conceived tax policies, corruption, lack of transparency in tax administration, and lack of integrated fiscal strategy that takes into account social taxes, local taxes, and fees when calculating the overall tax, impose huge burdens on the business community in Africa (Baurer, 2005; Rottger, 2003). Analyses of tax surveys led by the OECD and World Bank in 15 SSA countries' revenue bodies, offers insight into informative trends and patterns regarding tax administration (Carter \& Cebreiro, 2011). In all the revenue bodies surveyed, the cost of collection (a big challenge facing many developing countries) varies from $1 \%$ to $4 \%$ of the total collection, but the majority of revenue bodies lack investment in information technology with these systems accounting for less than $2 \%$ of total administrative expenditure. The Carter and Cebreiro study suggests that all the countries lack adequate enforcement law to collect penalties from offenders, although some claim to have effective enforcement. However, more positively, all the countries with the exception of Botswana and Mauritius have created special taxation regimes to facilitate the growth of small and microenterprises, but only six countries have set up a dedicated management unit.

\subsubsection{Economic infrastructure}


Economic infrastructure including transportation, electricity, irrigation, information and communication technologies is a pre-requisite for agribusiness development. Infrastructure constraints have implications for both domestic and foreign investors, particularly in terms of the cost and reliability of physical movement of raw materials and finished products, efficiency of processing operations and other key parts of a supply chain (Foster \& Briceño-Garmendia, 2010). Infrastructural status can also affect the rate of transition and stage of evolution of the agribusiness sector from informal to formal structures. A study by the World Bank and the Africa Development Bank on infrastructure in African countries shows that power is by far Africa's largest infrastructure challenge, with regular power shortages in as many as 30 countries, and many paying high premiums for emergency power (AfDB, 2013; Foster \& Briceño-Garmendia, 2010). There are almost 590 million people in SSA who lack access to electricity, and rely on the traditional use of biomass for cooking (WEO, 2010). In Nigeria, lack of adequate supply of electricity represents a significant threat to the country's aspiration to be among the top 20 economies in the world, by the year 2020. In 2008, access to electricity in both rural and urban SSA was found to be generally very low, compared to North African countries and the global average. In addition, only $42 \%$ of African countries had access to electricity in 2009 , compared to $78 \%$ in South East Asia and 93\% in Latin America (AfDB, 2013).

After power, transport is one of the most significant items of infrastructure that hampers marketing opportunities for smallholders (Foster \& Briceño-Garmendia, 2010; OECD, 2008; WEF-WB-AfDB, 2011) as the availability of good transportation infrastructure plays a crucial role in fostering agribusiness competiveness. The World Economic Forum, the World Bank and the African Development Bank assessed the potential competitiveness of agribusiness and ranked African countries based on 12 distinct pillars including infrastructure (WEF-WB-AfDB, 2011). 
Of 139 countries, only three African countries such as Mauritius, Namibia and Tunisia emerged as top-level performers on transportation infrastructure and ranked 58th, 54th and 46th, respectively. These countries, based on regional standards, have relatively good transportation systems, especially ports and good roads. The top half of the ranking on infrastructure is South Africa (63rd), Egypt (64th) and Gambia (69th) whereas the majority of countries in SSA ranked much lower on this major indicator. For example, in Tanzania, a large proportion of the agricultural harvest cannot reach market due to bad roads, high cost for transport and logistical services (OECD, 2008).

\subsubsection{Technological innovation}

Innovation and technological readiness, and the willingness to adopt new technology and invest in research and development (R\&D) drives economic agility and the growth of agribusiness (WEF-WB-AfDB, 2011). A comparative analysis of 144 countries, by the World Economic Forum, on innovation shows that African countries such as Tunisia, South Africa, Senegal and Kenya are the highest performers, ranked 31st, 44th, 55th, and 56th, respectively (Schwab, 2013). A very low ranking among the majority of countries in Africa indicates that they lack collaboration between industries, research institutes and universities with low investment in R\&D. According to UNESCO, Africa's contribution to the world's R\&D remain significantly lower than elsewhere, accounting for less than $1 \%$ of global investment in R\&D and a mere $1.5 \%$ of total scientific publications (UNESCO, 2010). In 2008, most African countries produced less than 100 scientific publications per annum. Of 11,142 scientific articles produced in this year in Africa, South Africa alone produced almost half (46.4\%) of total scientific publications, followed by Nigeria (11.4\%) and Kenya (6.6\%). South Africa also produced two-thirds of the Africa continent's utility patents (patent awarded to Africa by the United States Patent Office). South 
Africa, Nigeria and Kenya as three countries combined represent two-thirds of the subcontinent's scientific publications, and this is a reflection of their relatively sophisticated level of R\&D in those nations compared to other countries (UNESCO, 2010).

With regard to technological readiness, the top three North African countries (Tunisia, Morocco and Egypt), ranked 55th, 75th and 87th, respectively, and the two leading SSA countries, Mauritius and South Africa, ranked 61th and 76th out of 139 countries (WEF-WB-AfDB, 2011). In part, this reflects the low rates of access to ICT services, particularly in Africa which has the lowest internet penetration rate in the world, $26.5 \%$, as compared to world average of $42.3 \%$ (Internet World Stats, 2015).

The lack of investment and priority for science, technology and innovation (STI) underpins the gap between product development and commercialization undertaken by African public research institutions and private agribusiness, respectively. This is an obvious disconnect that exists across agro-industry value chains in the majority of African countries. For example, Evenson (2007) found that most of the technologies developed by the African based Consortium of International Agricultural Research Centers (CGIARs) in partnership with the National Agricultural Research Organizations had not been commercialized by the private sector (Evenson, Gollin, Evenson, \& Pingali, 2007). Part of the reason for this lack of commercialization is the weak protection of intellectual property rights in the region, which deters investment in local products and transfer of new technology. Indeed, although 18 agricultural research institutes and 3 agricultural universities in Nigeria had focused for a considerable time on the development of improved agricultural technologies that are relevant to local farmers, none of these had reached the market on a commercial scale (Dannson, Ezedinma, Wambua, Kirsten, \& Satorius, 2004; Flaherty, Ayoola, Ogbodo, \& Beintema, 2010). This could have a negative influence on the development 
of agribusiness in Nigeria and its sub-regions. Low use of modern inputs and limited access to innovative technologies represents one of the biggest challenges to the growth of competitive agribusiness industry in Africa (Byerlee, et al., 2013). Generally, the research capacity to support the development of agribusiness and to generate innovation is also lacking in most African countries. According to the United Nations, if per capita value of consumption increases by $25 \%$ in urban areas compared to rural areas, the urban market is likely to increase by four fold in the next two decades in Africa. In view of this projection, the key to achieving this transformation and upgrading is that, micro, small and medium enterprises in agro-value chains must shift from traditionally driven technology to innovation driven development. Emerging economies such as China, India, and Brazil are leading in applying innovative technologies to strengthen supply chain management, improve market services and reduce cost. The introduction of the Brazilian Agriculture Research Enterprise (EMBRAPA) revolutionized their tropical agriculture (de Freitas Filho, Paez, \& Goedert, 2002; Rada \& Valdes, 2012). EMBRAPA continues to broaden its scope in food technology, biotechnology, agro-energy and nanotechnology in order to stay relevant and be competitive in global food markets. Thus emerging technologies (Table 1) can make a large impact on the agribusiness sector in developing countries.

[Insert Table 1]

African governments can encourage innovation as part of building inclusive domestic and global markets. They will also have to invest in stronger R\&D orientation of local companies through intensified collaboration between research institutes, universities and the private sector.

\subsubsection{Land tenure system}

The use of land for agricultural development is one of the critical institutional features that determine economic characteristics of agriculture in developing countries. Land has a spiritual 
significance and is at the heart of the socio-political and economic life of the African population, as it currently provides employment for the majority of the people (Commission for Africa, 2005). Understanding social institutions, for example, property rights that govern land use and ownership will be important in the light of promoting agribusiness for economic growth. Property rights as an enforcement mechanism can help to resolve disputes regarding land use (Toulmin, 2009). The land use act (governing land use and ownership) in Nigeria, can impede the emergence of medium and large scale farming operations, which is seen as critical to agroindustrial development in the country (Yumkella, et al., 2011). For most land in SSA there is a lack of registration of the ownership rights, but many farmers consider their rights sufficiently secure under customary law (Toulmin, 2009). However, the rights of women and foreigners are often constrained under a customary land system that constitutes a major challenge to investment and innovation. Poor countries' central governments in developing nations, particularly in Asia, Africa and South America, usually have neither the capacity nor the local knowledge to implement large-scale national land registration system (Clover and Eriksen, 2009). With such a high proportion of land being unregistered, the lack of land registration and the risks of dispossession can be a hindrance not only for the poor (Toulmin, 2008) but also for agri-business development. The challenge is that these people have little access to the law and are excluded from formal land rights (Rudi et al., 2012). This problem therefore worsens land tenure conflicts between investors and local people. The investors could, besides land grabbing in itself, also grab a part of the political economy of agricultural investment. In this way, land tenure systems drive economic agility and the growth of agribusiness, but also bring forth some ethical questions with regards to indigenous people and the break of their connection with the land. Others might argue that what is happening in terms of land grabbing is no different to the land enclosure process in 
countries such as the United Kingdom in the 1800s. For example, a study by Lavers (2012) emphasizes that land deals in Ethiopia are the manifestation of the political economy of agricultural investment. By 2011, 26 Chinese companies have been actively in negotiation with Latin American and African countries to invest in agriculture (Azadi et al., 2013). In Latin America, especially Argentina and Brazil, millions of hectares of farmland have been taken over by foreign investors over the past few years for the production of food crops and agrofuels for export (Borras et al., 2011). GTZ (2010) reported the acquisition of about 1 million hectares of land by foreign investors in Cambodia between 1988 and 2006.

\subsection{Risk Factors}

\subsubsection{Political instability}

Due to the frequent crises and civil wars that affect many regions within the continent, the political and policy environment is an important factor that is often considered before any business activity takes place in Africa. Africa has experienced more deadly violent conflicts than probably any other continent in the world (Collier \& Hoeffler, 2004; Hoeffler, 2008) adversely affecting economic growth, FDI, and capital flows. In most cases company investment decisions are negatively affected by corruption, political and social instability, economic mismanagement and an uncertain regulatory environment that lead to increased costs and high risk in African countries. For example, in 2011, Consumer Package Goods Co. and many foreign companies ended their investments and businesses, due to internal social and political conflicts in Nigeria, and economic and political mismanagement in Zambia (WEF-B\&C-WB, 2013). While the degree of violence and the manner in which it is perpetrated varies from country to country, the key factors in fuelling political unrest are election problems and labor market inefficiencies, as noted in recent times in North Africa. Even, when political instability does not result in civil wars, it 
can unsettle the markets and create, for potential investors, uncertainty about the fiscal and economic policy within the country (Ongayo, 2008).

\subsubsection{Weak social infrastructure}

The institution of human capital and its role in socio-economic transformation is fundamental to agribusiness development in Africa. Access to education, healthy life and standard living are the three key elements of the Human Development Index (HDI) introduced by the UNDP in 1990 to track global evolution of human development around the world including African countries (UNDP, 1991). Access to primary education, skills and training underpins the development of agro-value chains and facilitates the transition of informal small business activities into the formal sector. These businesses often faces serious problems in enabling their workers to gain access to the basic skills and education required to enable them to evolve and compete in the contemporary and emerging agri-food economy. Illiteracy is one of the main factors affecting the use of information technology, and access to knowledge and information. According to the FAO, women represent over $60-80 \%$ of the labor force in agricultural and food production in Africa, but face unequal access to knowledge resources and services such as finance and skills that are fundamental to entrepreneurial development (FAO, 2011). A recent UNIDO study examined the role of better training tools in all key aspects of agribusiness to enable transformation of rural life and thereby creating wealth in African countries (UNIDO, 2013). This study targeted the upgrading of value chains, identified the training of the youth and women as key to improving agricultural production and food-processing capabilities.

According to the latest Human Development report, SSA has the most inequality in health (UNDP, 2013). As nutritional status rises, life expectancy at birth increases, which is an essential requirement for improving labor productivity. The impact of nutrition on labor productivity can 
be a significant contributing factor to agricultural transformation especially as the number of hours an individual could potentially work per day increases as nutritional status improves (Huffman \& Orazem, 2004). Average life expectancy at birth in Africa stands at 56 years (WHO, 2011), whereas it stands at 79.5 years in OECD countries (OECD, 2011a). According to the WHO, the presence of tropical, communicable (e.g., malaria, HIV/AIDS) and non-communicable diseases (e.g., diabetes, cancers) cause more than $60 \%$ of deaths in SSA. In addition, disease can reduce the physical ability to work, particularly among the youth and young breastfeeding women who are key to the future development of agri-food industries.

\subsubsection{Quality standards}

The lack of access to essential inputs for food testing, packaging, grading and distribution represents another major challenge in the agro-processing industry, hence limiting their ability to export final products. Laboratory equipment for testing and certification services, storage infrastructure and agro-processing facilities are either lacking or in very poor conditions in majority of African countries. All of these are important to meeting international quality and supply chain standards making it very difficult as a result to participate in the global value chain. For example, in Senegal, inability of the local industries to meet the high quality and safety standard as required by importing countries has shifted their focus onto domestic and regional markets (Yumkella, et al., 2011). Poor packaging facilities can reduce the opportunities for the development of new products that serve the demands of consumers on the domestic, national and international markets. Moreover, the impact assessment of infrastructure in Africa by the World Bank showed that lack of inputs such as irrigation and mechanization limit the production of local rice to meet urban market demands (World Bank, 2013). As a consequence, the perceived 
superiority of imports in terms of variety, quality and reliability affect the demand for local rice. Efforts in Senegal and Ghana to make local rice as competitive as imported rice from Thailand have made little or no difference due to the consistent quality of imported product which is not met by domestic product. The impediments to the availability of agricultural inputs could pose a serious threat to urban food markets that is projected to exceed \$US 400 billion (4-folds increase) by the year 2030 in Africa (World Bank, 2013).

\subsubsection{Climate change}

Africa is arguably the most vulnerable continent to the impact of climate change (Boko, et al., 2007). The spread of transboundary plant and pest diseases triggered by climate change can lead to huge losses to crops and pastures as well as epidemics of malaria and vector-borne diseases exposing many people to infection. Poor health as a result of the impact of climate change can slow down farm output, hence affecting agribusiness development. The irregular weather patterns leading to droughts, flash floods and reduced rainfall will compromise agricultural productivity, especially for subsistence farmers in SSA (Jarvis, Lane, \& Hijmans, 2008). It is proposed that as a result of global warming, arable land will be lost, with shorter-growing seasons and low yields resulting in lower agricultural productivity. Africa has a low adaptive capacity in this context so this poses a significant challenge to agribusiness development in African countries (Boko, et al., 2007).

\subsection{Summary}

Mhlanga (2010) states that the lack of access to markets and natural resources, good infrastructure, and a stable macroeconomic and political environment limits development in Africa (Mhlanga, Blalock, \& Christy, 2010). Further, mismanagement and/or weak regulation 
can generate serious issues for many poor people (Oxfam, 2012). In an attempt to fill the void, private sector investments can help provide resources such as technology and capital, and connect agricultural producers to the market. Therefore, it is important to consider the role of private sector investment in agribusiness and agro-industries in African countries and its contribution to the socio-economic development of the rural sector. By comparing with other developing countries in the Asia-pacific region this research has sought to identify innovative private and public sector policies, programs and institutions that can promote rural development and provide socio-economic benefits to farmers.

\section{Private sector agribusiness investment: The role in rural development of SSA and} Asia

The linkage of agribusiness and agro-industrial has potential to benefit the poor rural majority in developing countries (Tersoo, 2013). However, as has been previously described, despite their importance in the development process, the agribusiness and agro-industrial sectors face a number of problems, ranging from the vicissitudes of environment to the unusual vagaries of political discontinuities and inconsistencies (Dunmoye, 1987). In order to overcome these problems, promoting and supporting private sector agribusiness investment is a feasible strategy for improving rural development. In many countries of the Asia-Pacific region, food and agriculture systems are changing quickly towards market-driven systems, and private sectors play an increasingly important role while small-scale farming is commercializing and agribusiness and agro-industry are, to a great extent, influencing economic and social development. This development is supported by legal and regulatory frameworks that define the rules and identify rights and obligations with regard to resources, capitals and business operations thus mediating employment law and agreements that influence agribusiness profitability, as well as ensuring the 
distribution of the benefits resulting from agribusiness development. Despite the existence of such policy and program reforms and increased private sector investments, OXFAM (2012), argues in Southeast Asia, the unregulated arrival of huge numbers of private sector investments in agriculture is posing problems for many poor communities including food insecurity resulted from the agriculture land conversions to give a way for exports and biofuels plantations; the abandonment of lands by small-scale farmers to provide opportunity for the private investors; the adverse impacts of uneven bargaining power on farmers' wellbeing; and finally, environmental degradation.

Figure 1 shows the existence of large foreign and local companies across the agro-food supply value chain in SSA countries. At the regional level, countries in Southern Africa host the largest number of both foreign and local companies, followed by West Africa. At the country level, South Africa and Nigeria are the main countries in undertaking agribusiness activity, having the greatest number of companies (FAO, 2013a). Overall, country comparisons conducted by Mhlanga (2010), show that the size of the country's economy is the main determinant of agribusiness investment activity when measured by GDP or population size.

[insert Figure 1]

Other factors influencing private investment in agribusiness in this region include not only the positive factor of an abundance of natural agricultural resources, but also potential barriers such as the existing level of infrastructure development in an economy, the availability of a supportive macro-economic environment, challenges with corruption and/or trade regulation, political instability, limited access to not only finance and technology, but also institutions and support services, and the degree of development of farmer/producer organizations (Mhlanga, 2010). 
Investments in agriculture have also benefited from a wide range of policy reforms utilized by countries in SSA to enhance their internal foreign direct investment (FDI) flows. African countries have tended to standardize entry and operating situations for FDI along with other countries and to decrease the risk of investing in their countries (UNCTAD, 2008). In this context, many countries now participate in international investment agreements and conventions and have even set up investment promotion agencies (IPAs) to provide local and foreign investors an opportunity for their investment (Ajaegbu, 2014). Despite having established critical policy reforms over the past few decades, the business environment is still far from being favorable for agribusiness (FAO, 2013a). IEG (2011) conducted a meta-analysis on the impact(s) of the interventions undertaken by the private sector including an impact evaluation of land tenancy and titling interventions, irrigation interventions, extension intervention, improved natural resource management, technology interventions, input technology interventions, marketing interventions, and microfinance interventions (IEG, 2011). They concluded that there were benefits to be derived from interventions related to the input technology (and output enhancement). However the report also emphasized that the role of government is important in enabling policy reforms related to marketing, land and microcredit interventions. Therefore, to keep the upward movement and to activate the great potential for attracting private investment in agribusiness and agro-industries, there is a need to address policies and laws influencing agricultural production, the official supportive environment of the investment as well as the whole investment climate in the target country (FAO, 2013a). As Nigeria (Africa) and Thailand (Asia) have been the world's largest producers of cassava over the past two decades, the two countries are used as case studies to consider the role of cassava innovation in agribusiness 
development and how the drivers that have been discussed play a role the development of a competitive cassava value chain.

\section{Case study of Cassava Value Chains in Thailand and Nigeria - lessons on Agribusiness Development}

\subsection{Importance of cassava industry}

Cassava is a crop that can survive drought and poor soils making it as a result of primary importance to agricultural communities in many parts of the world (Shigaki, 2016). Cassava production is known to be the fastest rising staple crop globally (OECD-FAO, 2015). Around the world, Nigeria (Africa), Brazil (Latin America) and Thailand (Asia) are the top three countries with the highest cassava production over the past two decades (Figure 2). Cassava plays a significant role and is indispensable to food security, energy security, poverty reduction and has economic importance for millions of smallholders in developing countries including countries in Africa, and as an industrial use for biofuel production and animal feed in Asia and Latin America which brings microeconomic benefits for these regions (OECD-FAO, 2015). Large scale commercialization and rapid investment in scaling up processing and value chains of cassava is largely driven by these factors. Globally, only few countries such as Thailand, Vietnam, Indonesia, China and Brazil represent high value added cassava markets (Poramacom, Ungsuratana, Ungsuratana, \& Supavititpattana, 2013). Of these countries, the cassava market is largely dominated by Thailand. For example, in 2013, Thailand represented the largest market share of cassava exports (FAO, 2013b). In most Africa countries, cassava production is mainly driven by domestic consumption and local market partly due to lack of R\&D support, lack of required skills for processing and limited financing. Despite these challenges, according to FAO, 
over $60 \%$ of global cassava production will still remain in sub-Sahara Africa countries by year 2020 and continue to support domestic economy.

As a result of the flexibility in harvesting cassava and also its ability to adapt to harsh conditions, cassava has significant potential as one of most climate change resilient crops, addressing a risk highlighted earlier in this paper. Cassava roots are a good source of carbohydrate, calcium and vitamin C, but are poor in terms of protein and fat (Shigaki, 2016). A shift in the cassava sector to a more innovative industry producing products such as flour, glucose, noodles, biscuits, starch, ethanol and well packaged traditional food could significantly enhance agribusiness development in Africa. Due to its high carbohydrate content, cassava is also gaining wider recognition as a potential renewable biomass fuel (Adinurani, et al., 2015; Campos Benvenga, Henriques Librantz, Curvelo Santana, \& Tambourgi, 2016; Elemike, Oseghale, \& Okoye, 2015; Okudoh, Trois, Workneh, \& Schmidt, 2014). This is of specific interest in Nigeria following a historic electricity provision shortfall (Aliyu, Dada, \& Adam, 2015). These products will have an important role to play in sustaining food security due to a high dependence on cassava production in many African countries, as well as enhancing economic growth due to a rising demand in the global cassava industry.

[Insert Figure 2]

Nigeria is by far the largest producer of cassava in the world (FAO, 2012) and the production system is characterized by highly subsistent and low-input smallholder farmers, cultivating an average farm size of between 0.5 and 2.0 hectares each. Cassava is processed in the informal sector, primarily for a domestic and traditional food market, into flour, gari and fufu. Other cassava products that can be produced on a medium-to-large scale include starch, feeds, chips and ethanol. However, there is little or no industrial usage in Nigeria, partly due to weak 
institutional capacity and limited financial resources. Export opportunities could position Nigeria as a key supplier in the regional market. An estimated 12.7 million tonnes of fresh roots is produced for foreign exports combined with the domestic and regional exports creating jobs for over a million Nigerians (Table 2).

[Insert Table 2]

Cassava is a cash earning crop, ranked third most important after rice and sugarcane in Thailand. Unlike Nigeria, where smallholders are the predominant producers in Thailand cassava production system is characterized by small, medium and large farms. The smallholders cultivate an average size of between 2 and 4 hectares, medium farmers cultivate an average size of between 4 and 16 hectares and large farmers cultivate above 20 hectares (Bhuthong \& Panpiemras, 2009). The main areas of cassava production are in North-Eastern, Central and North, accounting for 55\%, 25\% and 20\% respectively (Likhitvidhayavuth, 2013). Thailand was the first country to commercialize and start large scale industrial production of cassava. Cassava is commercially produced for animal feed, ethanol and starch-based products with more than $70 \%$ produced for export and $20 \%$ produced for domestic use (Table 3 ).

[Insert Table 3]

Thailand has successfully developed a thriving innovative business in the cassava industry often called the Tapioca industry, where cassava products such as modified starch, chips and pellets are largely exported to the EU, US and Asia. Thailand first exported cassava product to Europe in the 1970s, where it was mostly used as animal feed by the livestock industry, and enjoyed a strong business relationship with the EU for three decades (FAO, 2013c). This was driven by the EU's 
Common Agricultural Policy (CAP) and led to high cereal price, which became a market for cereal substitutes that could enter the EU with low tariff levels. The EU's market dominant position of $88 \%$ of Thailand's exports in 1995 dropped to just $10 \%$ in 2005 . The decline in 2005 was due to the EU policy reforms that favored cereals over cassava. In spite of the loss of the EU markets, Thailand still dominates the export trade in cassava, earning a total value of 1.5 billion dollars from 6 million tonnes of dried cassava chips and starch in 2010 (FAO, 2013c). Figure 3 shows export volume of cassava products in Thailand between 2001 and 2012. In 2012, $100 \%$ of Thai chips and 24\% of modified starch were exported to China (Likhitvidhayavuth, 2013).

[Insert Figure 3]

Also, in the same year, $45 \%$ of pellet was exported to the US while $33 \%$ of modified starch was exported to Japan.

\subsection{Comparative analysis of the two case studies}

A comparison of the Nigeria and Thailand case studies shows why the latter country has developed a competitive cassava value chain and strong market linkages in the cassava agribusiness sector. As has been previously described in this paper, there are drivers and risk factors that influence agribusiness development in developing countries. The drivers and risk factors that were discussed in section three have been critiqued as part of this research to consider six cross-cutting pillars of global competitiveness that influence a competitive cassava value chain. Figure 4 illustrates how the different characteristics interact to develop a competitive cassava value chain.

[Insert Figure 4) 
According to Figure 4, overall for the six key cross-cutting pillars of global competitiveness considered Thailand is ranked at 38 and Nigeria at 115 out of a total of 144 countries considered. These six cross-cutting pillars of global competitiveness are now explored further: macroeconomic (see 5.2.1), infrastructure (see 5.2.2), institutions (see 5.2.3), strategic marketing (see 5.2.4) which encompasses many of the pillars previously described too, innovation (see 5.2.5 and 5.2.6), higher education and training (see 5.2.6).

\subsubsection{Agro-industrial policy}

The Thai agricultural sector was first prioritized in terms of investment policy in 1958, and then a full-scale, export-led agro-industrial policy promoting the production of cassava starch, chips and pellets export market followed benefiting the cassava industry (Howeler \& Hershey, 2001; Liu, Koroma, Arias, \& Hallam, 2013). The result is a competitive cassava value chain at the domestic and global market level by ensuring that the industry has access to finance and supporting farmers' ability to engage in improved farm production activities. Since 1960s, the Nigerian government's agro-industrial policy toward cassava industry has consistently failed. Possible explanations are that between 1961 and 1971 the government's policy only focused on industrial crops such as cocoa, cotton, oil palm, rubber and groundnut in terms of export revenue (Nweke, Spencer, \& Lynam, 2002), and most of these industries have struggled to survive. A combination of other factors including corruption, change of administration and lack of priority is responsible for non-competitive agribusiness sector in cassava industry as Nigerian economy is largely driven by oil industry. Adeniyi, Oyinlola, Omisakin, \& Egwaikhide (2015) conclude, from their work on financial development and economic growth in Nigeria, that efforts at amending the scope of the financial system in terms of size and level of activity need to be developed further together with wider structural reforms. Further, "commercial bank loans on agriculture, interest rate and food 
import value are significant variables that affect agricultural output in Nigeria whereas exchange rate, inflation rate and unemployment rate are insignificant" (Oluwatoyese et al. 2016:567).

\subsubsection{Infrastructure}

Ibem (2009) characterized the challenges with weak infrastructure in a developing economy as including economic and political crises and weak governance, rapid urbanization, inefficient structural delivery and low investment. Good quality infrastructure is a key ingredient to industrialization and enhances the ability to trade in a global market. Investment in infrastructure has contributed a great deal to the competitiveness of the cassava industry in Thailand. Howeler and Hershey (2001) and World Bank (2009) propose that earlier investments by the Thai government in processing facilities, roads and harbor infrastructure gave a competitive edge over its neighbors in the cassava industry (S. Fan, Jitsuchon, \& Methakunnavut, 2004; Word Bank, 2009). Efficiency and effectiveness in Thai processing including increased mechanization as well as export infrastructure has strengthened the supply chain and generated large-scale economies. Rural roads experienced rapid growth, from $6,258 \mathrm{~km}$ to $67,138 \mathrm{~km}$ in 1977 and 2000, respectively, a 10-fold increase over twenty years. In Nigeria in comparison, there is an absence of mechanization, lack of agro-processing and storage facilities and a dilapidated railway system and poor roads; all these factors contributing to high production and transportation costs. Seedhouse, Johnson, \& Newbery (2016) state that poor quality of the roads in Nigeria affects business growth in rural areas especially as few are paved and they become impassable in the wet season.

\subsubsection{Institutional support}

The presence of strong institutional capacity in terms of research and development (R\&D) and human resource development in public institutions plays an important role in the Thai cassava 
industry as compared to the Nigerian industry. Thailand has invested more in cassava R\&D, and trained farmers and many scientists across different research institutes and universities through well coordinated national programs and international joint research projects. For example, in 1993, a five year joint cassava research project brought together several scientists and social scientists from different institutions in Thailand, China, Vietnam and the International Center for Tropical Agriculture (CIAT) for training and exchange of knowledge to enhance cassava productivity (FAO, 2013c; Howeler, 2007). This has led, over the past 30 years, to the distribution of superior and high-yielding, disease resistant and drought tolerant cassava varieties. The joint commitment and collaboration between national and international research institutes drives new innovation and development of viable competitive cassava industry.

In Nigeria, the lack of support from the Ministry of Agriculture and the Ministry of Science and Technology and limited investment in national R\&D institutions such as the National Roots Crop Research Institute (NRCRI), Nigerian Stored Products Research Institute (NSPRI) and specialized universities of agriculture has weakened the cassava industry. The disconnect between research institutes and the Nigeria-based international Institute of Tropical Agriculture (IITA) has resulted in a small number of new cassava improved varieties and poor distribution systems mean that most Nigerian farmers have little or no access to improved varieties. For example, the Nigerian cassava yields are 8 tons/ha, compared to 25 tons/ha in Thailand (Table 3 ). [Insert Table 3]

While cassava yields have increased at an average of $1.7 \%$ per year over the past 15 years in Thailand, cassava yields have stagnated for almost two decades in Nigeria (FAO, 2012). 
According to the FAO, the cost of fresh root production per tonne in Nigeria is US $\$ 10$ higher than in Thailand making the cassava industry less competitive in the international market.

\subsubsection{Strategic marketing}

In Thailand, an effective marketing strategy has also played an important role in the global market competition and dominance within the cassava industry over the past three decades. In contrast, the Nigerian marketing for cassava products as industrial raw-materials has remained largely unexploited. Moreover, the inefficient marketing system and poor distribution networks have contributed to large marketing margins, irregular supply, unstable demand and fluctuating prices. In Thailand's case, the governments' efforts have been geared toward constant improvement and maintenance of the quality of cassava-based products such as high ethanol yields and root starch contents in order to meet the high standard and market requirements. The performance of market organization has been consistent and is the key to global competitiveness and the success story behind cassava market dominance by the Thailand. Market-driven innovation continues to be part of government strategies to remain competitive in the global market. For example, the opening of new shipping routes is strategic toward promoting and strengthening agribusiness in the Thai cassava trade (Stock Market, 2013). In order to speed up high quality cassava production and to meet increasing market demand, the Thai action plan for the development of cassava marketing is focused on the following three important areas: 1) promote and develop future market for cassava products; 2) undertake market access negotiation proactively with new potential markets, targeting countries in the Middle East and Africa; 3) intensive negotiation on tariff reduction with high tariff importing countries to expand Thai cassava export markets. Here, trade policy that focuses on investment liberation and tariff 
reduction is high in the Thai bilateral agreement, thereby encouraging a wider market opening for trade in agricultural and industrial products (Liu, et al., 2013).

\subsubsection{Vertical integration}

Vertical integration plays an important role in absorbing total cost and price risks across cassava value chains to ensure farmers are integrated into diversified markets in Thailand. The role of the private sector both in cassava production and processing technology cannot be overemphasized in the country. For example, in the Northeast of Thailand, apart from distribution of high yielding cassava varieties coordinated by the private sector, they ensure that cassava farmers sell their products directly to processing factories located around the planting areas (Ekasingh, Sungkapitax, Kitchaicharoen, \& Suebpongsang, 2007). This serves as an effective strategy for reducing production cost and labor cost while linking smallholders to growth markets, and hence improving trade competitiveness. Moreover, the private sector is a key partner in government initiative that helps strengthen the mechanization of cassava production in the country (Howeler \& Hershey, 2001). This translates into significant agro-industry investment by the private sector with a focus on cassava production as feedstocks where they continue to shape the ongoing transformation of agriculture in Thailand (GDPRD, 2011). The private sector seeks an economy of scale that integrates smallholders into global value chain especially in production, marketing and distribution. The Thai government also provides strong assistance in export development including the strengthening of public $\mathrm{R} \& \mathrm{D}$, whilst the private sector mostly manages internal market development for the cassava products. In Nigeria, vertical integration of smallholders and processors into cassava export market is virtually non-existent due to the lack of involvement of private sector; low quality cassava products and poor infrastructure. 


\subsubsection{Operations management-innovation and human capital}

In Thailand, the cassava industry has skilled human resources in the technical and managerial aspect of medium and large-scale farming across the value chains in the country. The investment in training and management of good farm practices such as best cassava planting time, mechanical land preparation, proper application of fertilizer, timely harvesting and weed control and other methods of best agronomic practices that are implemented by the agricultural extension officers and farmers, represent a major success in the Thai cassava industry. The availability of well trained personnel, harvesting machinery and processing technologies comes with many advantages including reducing harvesting time, production and operational costs while increasing working efficiency to ensure timely delivery of high quality cassava products (Howeler, 2007; TGP, 2007). Taken together, it shows that Thailand has firstly effective operationalization, secondly explicit strategy implementation and finally management team quality that help facilitate competitive cassava value chain.

Ogundeinde \& Ejohwomu (2016) suggest that there is a disequilibrium in supply and demand for "skilled and proficient manpower" in Nigeria and as a result has limited development by a failure to use the existing human and natural resources. In Nigeria, the cassava industry is dominated by semi-skilled and unskilled manpower that makes it difficult to coordinate the development of cassava products and markets as provider skills are weak across the cassava value chain. Moreover, the cost of farm inputs and mechanized machinery represents a significant barrier in Nigeria as majority of the farmers receive limited assistance from the government (Knipscheer, et al., 2007; Nweke, et al., 2002). Lack of transparency at state and national levels undermines the value chain and agribusiness development in the cassava industry. Schut, et al., 
(2016) assert that innovation in terms of productivity (fertilizer use, new varieties), national resource management, such as improved water harvesting and institutional innovation (policies and markets), with specific focus on the latter lie at the heart of a sustainable intensification approach in a given supply chain. The constraints to agricultural development that they highlight mirror those identified in this paper.

\subsection{Summary}

The differences in terms of the cassava industry in Thailand as compared with Nigeria can be explained by the six key cross-cutting pillars of global competitiveness index (Figure 4). Without doubt, the four key pillars where Nigeria is considerably lagging behind Thailand are: institutions, infrastructure, health and primary education and higher education and training. What can the Nigerian government learn from Thailand's experience in making the cassava industry more competitive in global market? As an outcome of this research, a contextual map has been developed (Figure 5) that seeks to draw together the steps required to strategically manage the translation between the existing structures within the cassava supply chain in order to develop a more value-orientated and multiple market focused industry.

[See Figure 5].

Figure 5 highlights the process within the proposed strategic plan with emphasis on overarching agro-industrial policy, developing infrastructure, promoting institutional support alongside the creation of a strategic marketing plan. At an operational level the development of more vertical integration in the Nigerian cassava supply chain as well as a clear operations management plan will ensure that strategic goals are delivered. A well-coordinated cassava development program is critical to the expansion of the cassava industry in Nigeria, particularly both in terms of 
commercial production and marketing. The Nigerian government must set up a committee that will oversee cassava production at the federal levels and across the thirty-six states within the country. It should be coordinated between different sectors led by the Ministry of Agriculture. One of the main tasks of this committee is to ensure that effective cassava production and development measures are introduced for product processing and marketing (NEPAD/FAO, 2006). This must target and attract commercial farming investors to encourage rapid expansion of commercial cassava production. Another important role for the task committee is to address and develop a coordinated solution to transport problem particularly in majority of the states with largest production of cassava. A well coordinated logistic system and specialized transport provider could increase market efficiency and enhance cassava industry. All of these should form the basis of action plan that foster rapid cassava production so as to meet market demands Strategic management must be supported by research and development (R\&D). The supply, operation and sales of cassava products requires strategic management too that is underpinned by R\&D. Increasing cassava productivity and its product value needs appropriate cassava varieties, increased mechanization, and pre-post, harvested and processing technologies through investment in $R \& D$. The strategic management practices that focus on $R \& D$ and new innovation should be targeted toward promoting domestic utilization, increased yields, high quality cassava and value added products. This can increase efficiency and productivity, reduce cost of production and promote competitive cassava industry both at the regional and global markets.

There must be coherent and inclusive policy dialogue. Nigerian' government policy for cassava production needs overhauling and must be coherent and inclusive. The key stakeholders including farmers, academia, public and private sectors in cassava production and industry must be consulted to understand and address their perspectives on the development of new government 
policies. Interaction with relevant stakeholders can help government on how to design and implement interventions particularly those policies that target logistic, trading, R\&D and technology transfer. For example, the Nigerian government must promote and develop new markets for its cassava product through negotiation with countries in Africa and other continents. This will require an inclusive policy dialogue and could, if implemented by the government, significantly improve Nigerian cassava industry in the next 10 years.

Efforts to increase yield, improve processing methods and market demand are underway. The previous President Jonathan and his Minister of Agriculture, worked under the former transformation agenda, to introduce policies to encourage the blending of cassava flour with imported cereals. For example, a blending ratio of up to $40 \%$ is expected by the year 2015 for cassava inclusion in bread making, from the current 20\%. In addition, in 2012, an agreement between Nigeria and China indicated that, Nigeria will supply at least 1 million (MT) of cassava dried chips annually, while there is an agreement between Nigeria and Australia to supply 500, 000 MT (FAO, 2012). However, Nigeria faces stiff competition as Thailand has a wellestablished export market with China and continues its global market dominance. In view of this fact, Nigeria will need to pursue an aggressive policy that targets domestic and regional market while strengthening export market trade by improving the quality of cassava products. To address this, one option for Nigeria could be to increase bioethanol production.

\section{Conclusion and policy implication}

This paper provides a valuable and timely contribution to agribusiness development in Africa.

The study examines key drivers and risk factors that affect the development of agribusiness in Africa whilst relying on empirical evidence from the literature and documented reports. Two case 
studies are examined with a comparative analysis between the two countries examining the interaction of key success drivers related to the development of competitive cassava industry in Thailand. This study argues that an enabling policy environment that includes export led agroindustrialization, research and infrastructural investments, strategic innovation and management, and reduced trade barriers would play a significant role in developing competitive cassava industry in Thailand at the global market. Apart from the two case studies, a valid argument based on the facts obtained from literature regarding agribusiness success in industrialized countries is drawn on how to foster the development of new business model and help build a strong and competitive agribusiness in Africa.

A viable agribusiness development can be achieved through increasing public-private investment partnerships and policy framework that encourages the integration of domestic economy into the global market, and a better coordination of the informal sector as it will continue to be part and parcel of the livelihood of poor people for a long time in the continent. There should be more emphasis on the reform of property leasing rights or land ownership rights at all levels of the governments (Toulmin, 2009), which are fundamental when considering downstream industry efficiency for starting agribusiness industries. There is also need to encourage rural education that integrates development of technical skills among the youth and with women for agribusiness development (Poole, Álvarez, Penagos, \& Vázquez, 2013). This also study highlights the role each ministry could play across different government agencies to facilitate successful agribusiness and value chain development (Table 4).

[Insert Table 4] 
The key ministries (agriculture, science \& technology, finance, trade) in Nigeria could play a leading role in promoting farming practices, technology development, provision of credits and coordination of business models, respectively, although, a cohesive policy approach is essential. Furthermore, trade policy plays an important role in developing competitive agribusiness (Renwick, Islam, \& Thomson, 2012). Here, the development of trade policy that takes into account smallholders at the heart of national strategy should be encouraged. The African regional organizations including the African Union (AU), Economic Community of West African Countries (ECOWAS) and Common Market for Eastern and Southern Africa (COMESA) can play a crucial role in trade negotiation at the regional and international levels to strengthen the agribusiness linkages. For the future of agribusiness development in Africa, there are some enabling policy avenues that are discussed in this paper that can support and monitor agribusiness development in the region. 


\section{References}

Abbey, L. A., Baer, W., \& Filizzola, M. (2005). Growth, Efficiency and Equity: The Impact of Agribusiness and Land Reform in Brazil, University of Illinois: CIBER Working Paper 05-0109.

Adeniyi, O., Oyinlola, A., Omisakin, O., \& Egwaikhide, F. O. (2015). Financial development and economic growth in Nigeria: Evidence from threshold modelling. Economic Analysis and Policy, 47, 11-21.

Adenle, A. A., Sowe, S. K., Parayil, G., \& Aginam, O. (2012). Analysis of open source biotechnology in developing countries: An emerging framework for sustainable agriculture. Technology in Society, 34, 256-269.

Adinurani, P. G., Nindita, A., Mel, M., Outhred, H., Elcome, C., Vincevica-Gaile, Z., Kuan, L. K., Setyobudi, R. H., Widodo, Y., Wahyuningsih, S., \& Newby, J. (2015). Conference and Exhibition Indonesia New and Renewable Energy and Energy Conservation (The 3rd Indo EBTKE-ConEx 2014)Fuelling Cassava Development to Meet the Greater Demand for Food and Bio-fuel in Indonesia. Energy Procedia, 65, 386-394.

AfDB. (2013). An Integrated Approach to Infrastructure Provision in Africa. Africa Development Bank.

African Economic Outlook. (2009). Technology Infrastructure and Services in Africa. http://www.africaneconomicoutlook.org/en/in-depth/ict-africa/technology-infrastructure-andservices-in-africa/. Accessed May 13, 2013.

Ajaegbu, C. C. (2014). Promoting foreign direct investment (FDI): The case of Uganda, International Journal of Research in Business Management 2: 2347-4572.

Aliyu, A. S., Dada, J. O., \& Adam, I. K. (2015). Current status and future prospects of renewable energy in Nigeria. Renewable and Sustainable Energy Reviews, 48, 336-346.

Baurer, L. I. (2005). Tax Administrations and Small and Medium Enterprises (SMEs) in Developing Countries Small and Medium Enterprise Department, World Bank Group, Washington DC.

Azadi, H., Houshyar, E., Zarafshani, K., Hosseininia, G., \& Witlox, F. (2013). Agricultural outsourcing: A two-headed coin? Global and Planetary Change, 100, 20-27.

Bhuthong, P., \& Panpiemras, J. (2009). Agriculture Trade Study within the Greater Mekong Subregion:Thailand Case Study, Thailand Development Research Institute. Phnom Pen Cambodia, October, 7-8.

〈http://www.cdri.org.kh/dan/conf78oct09/d2/3.\%20Mr\%20Punpreecha\%20Bhuthong\%20\%20Thailand.pdf $>$

Accessed, August 5, 2013.

Binswanger-Mkhize, H. P., McCalla, A. F., \& Patel, P. (2010). Structural Transformation and African Agriculture. Global Journal of Emerging Market Economies 2: 113-52.

Boko, M., Niang, I., Nyong, A., Vogel, C., Githeko, A., Medany, M., Osman-Elasha, B., Tabo, R., \& Yanda, P. (2007). Africa. Climate Change 2007: Impacts, Adaptation and Vulnerability. Contribution of Working Group II to the Fourth Assessment Report of the Intergovernmental Panel on Climate Change, M.L. Parry, O.F. Canziani, J.P. Palutikof, P.J. van der Linden and C.E. Hanson, Eds., Cambridge University Press, Cambridge UK, 433-467.

Byerlee, D., Garcia, A. F., Giertz, A., \& Palmade, V. (2013). Growing Africa Unlocking the Potential of Agribusiness. The World Bank. Washington, DC.

Campos Benvenga, M. A., Henriques Librantz, A. F., Curvelo Santana, J. C., \& Tambourgi, E. B. (2016). Genetic algorithm applied to study of the economic viability of alcohol production from Cassava root from 2002 to 2013. Journal of Cleaner Production, 113, 483-494. 
Borras, S.M., Franco, J.C., Kay, C., \& Spoor, M. (2011). Land grabbing in Latin America and the Caribbean viewed from broader international perspectives. The Latin America and Caribbean seminar: 'Dinámicas en el mercado de la tierra en América Latina y el Caribe', 14-15 November, FAO Regional Office, Santiago, Chile.

Carter, A., \& Cebreiro, A. (2011). Africa's tax system: A survey. OECD Centre for Tax Policy and Administration.

Chaddad, F. R., \& Jank, M. S. (2006). The Evolution of Agricultural Policies and Agribusiness Development in Brazil. Choices , 21 (2006) 2.

Chaudry, Q., Scotter, M., Blackburn, J., Ross, B., Boxall, A., Castle, L., Aitken, R., \& Waekins, R. (2008). Applications and implications of nanotechnologies for the food sector. Food Additives and Contaminants, 25 (3) 241-258.

Clover, J., \& Eriksen, S. (2009). The effects of land tenure change on sustainability: human security and environmental change in southern African savannas. Environmental Science \& Policy, 12, 53-70.

Colin, J.-P. (2013). Securing rural land transactions in Africa. An Ivorian perspective. Land Use Policy, 31, 430-440.

Collier, P., \& Hoeffler, A. (2004). "Greed and grievance in civil war",Oxford Economic Papers: 56, 563-95.

Commission for Africa. (2005). Our Common Interest: Report of the Commission for Africa, London.

Dannson, A., Ezedinma, C., Wambua, T. R., Kirsten, J., \& Satorius, K. (2004). Strengthening farmagribusiness linkages in Africa. Summary results of five countries studies in Ghana, Nigeria, Kenya, Uganda and South Africa. Food and Agricultural Organizations of United Nations (FAO), Rome.

de Freitas Filho, A., Paez, M. L. D. A., \& Goedert, W. J. (2002). Strategic planning in public R\& D organizations for agribusiness: Brazil and the United States of America. Technological Forecasting and Social Change, 69, 833-847.

Demirbas, M. F., Balat, M., \& Balat, H. (2009). Potential contribution of biomass to the sustainable energy development. Energy Conversion and Management, 50, 1746-1760.

Dunmoye, A. (1987). Agricultural and Economic Growth with Special Reference to the Developing Countries: A Survey of Relevant Theories, in: O. Oculi (Eds.), Nigerian Alternatives. Zaria, Nigeria, ABU University Press.

EC. (2013). -European Commission: Agribusiness and Development: How investment in the African agrifood sector can help support development. Seminar co-organised with DG Development and Cooperation EuropeAid. Charlemagne, Brussels

Ekasingh, B., Sungkapitax, C., Kitchaicharoen, J., \& Suebpongsang, P. (2007). Competitive Commercial Agriculture in the Northeast of Thailand. Department of Agricultural Economics and the Multiple Cropping Center. Faculty of Agriculture, Chiang Mai University, Thailand.

Elemike, E. E., Oseghale, O. C., \& Okoye, A. C. (2015). Utilization of cellulosic cassava waste for bioethanol production. Journal of Environmental Chemical Engineering, 3, 2797-2800.

Evenson, R. E., Gollin, D., Evenson, R., \& Pingali, P. (2007). Chapter 46 Contributions of National Agricultural Research Systems to Crop Productivity. In Handbook of Agricultural Economics (Vol. Volume 3, pp. 2419-2459): Elsevier.

Fan, S., Hazell, P., \& Thorat, S. (2000). Government spending, growth, and poverty in rural India, American Journal of Agricultural Economics 82 (2000) 1038-1051.

Fan, S., Jitsuchon, S., \& Methakunnavut, N. (2004). 'The Importance of Public Investment for Reducing Rural Poverty in Middle-Income Countries: The Case of Thailand.' DSGD Discussion Paper 7. Washington, DC: IFPRI. .

FAO. (2011). The role of women in agriculture. The Food and Agricultural Organisation of United Nations. EAS Working Paper No. 11-02. 
FAO. (2012). Trade and Markets Division.Food Outlook. Global Market Analysis. Global Information and Early Warning System on Food and Agriculture (GIEWS).

FAO. (2013a) Trends and impacts of foreign investment in developing country agriculture . Evidence from case studies http://www.fao.org/docrep/017/i3112e/i3112e.pdf Accessed October 31, 2016.

FAO. (2013b). Food Outlook Biannual Report on Global Food Markets. http://www.fao.org/docrep/019/i3473e/i3473e.pdf Accessed July 31, 2016.

FAO. (2013c). Save and Grow Cassava- A Guide to Sustainable Production Intensification. Food and Agricultural Organisations of the United Nations, Rome.

Flaherty, K., Ayoola, G., Ogbodo, J., \& Beintema, N. (2010). Nigeria Recent Development in Agricultural Research. International Food Policy Research Institute. Washington DC. Country Note, October.

Foster, V., \& Briceño-Garmendia, C. (2010). Africa's Infrastructure. A Time for Transformation. The World Bank, Washington, DC 20433.

GDPRD. (2011). Global Donor Platform for Rural Development (GDPRD).The strategic role of the private sector in agriculture and rural development: Thailand working paper.

GTZ. (2010). Foreign Direct Investment (FDI) in Land in developing countries, Eschborn, GTZ, http://farmlandgrab.org/11084 (accessed 15 December 2014).

Hoeffler, A. (2008). Dealing with the Consequences of Violent Conflicts in Africa. Background Paper for the African Development Bank Report

Howeler, R. H. (2007). Sustaining cassava farmers and our earth : Background of the Nippon Foundation project in Asia. International Center for Tropical Agriculture(CIAT). Regional Cassava Office Asia. Field Crops Research Institute, Dept of Agric. Chatuchak, Bangkok 10900, Thailand.

Howeler, R. H., \& Hershey, C. H. (2001). Cassava in Asia: Research and Development to Increase its Potential Use in Food, Feed and Industry- A Thai Example.

Huffman, W., \& Orazem, P. (2004). The Role of Agriculture and Human Capital in Economic Growth: Farmers, Schooling, and Health. lowa State University. Working Paper. No: 04016

Ibem, E. O. (2009). Community-led infrastructure provision in low-income urban communities in developing countries: A study on Ohafia, Nigeria. Cities, 26, 125-132.

Ibrahim Forum. (2011). African Agriculture: From Meeting Needs To Creating Wealth. Mo Ibrahim Foundation, Tunis, November, Revised Edition.

IEG. (2011). -Independent Evaluation Group:Impact Evaluations in Agriculture: An Assessment of the Evidence. The World Bank. Washington, DC.

IMF. (2010). Regional Economic Outlook - Sub-Saharan Africa - April 2010. IMF, Washington DC.

IMF. (2014). Regional Economic Outlook. Sub-Saharan Africa. Washington, D.C. International Monetary Fund.

Internet World Stats. (2015). World Internet Penetration Rates by Geographical Regions. http://www.internetworldstats.com/stats.htm. Accessed June.

Jalan, J., \& Ravallion, M. (2002). Geographic poverty traps? A micro model of consumption growth in rural China, Journal of Applied Econometrics 17, 329-346.

Jarvis, A., Lane, A., \& Hijmans, R. J. (2008). The effects of climate change on crop wild relatives. Agriculture Ecosystems \& Environment, 126:13-23.

Jouanjean, M. A. (2013). Targeting infrastructure development to foster agricultural trade and market integration in developing countries: an analytical review, Overseas Development

Institute, London. odi.org. Accessed 10 July, 2015

Kiiza, B., \& Pederson, G. (2012). ICT-based market information and adoption of agricultural seed technologies: Insights from Uganda. Telecommunications Policy, 36, 253-259. 
Kimatu, J. N., McConchie, R., Xie, X., \& Nguluu, S. N. (2012). The Significant Role of Post-Harvest Management in Farm Management, Aflatoxin Mitigation and Food Security in Sub-Saharan Africa. Greener Journal of Agricultural Sciences. 2(6):279-288.

Kitinoja, L., Saran, S., Roy, S. K., \& Kader, A. A. (2011). Postharvest technology for developing countries: challenges and opportunities in research, outreach and advocacy. Journal of the Science of Food and Agriculture, 91, 597-603.

Knipscheer, H., Ezedinma, C., Kormawa, P., Asumugha, G., Makinde, K., Okechukwu, R., \& Dixon, A. (2007). Opportunities in the Industrial Cassava Market in Nigeria. International Institute for Tropical Agriculture (IITA).

Kormawa, P. M., Wohlmuth, K., \& Devlin, J. (2011). Agribusiness for Africa's Prosperity: Country Case Studies, Working Paper, Second Edition, April 2012.

Kuzma, J., \& VerHage, P. (2006). Nanotechnology in Agriculture and Food Production: Anticipated Applications (Washington, DC: Woodrow Wilson International Center for Scholars, Project on Emerging Nanotechnologies).

Lavers, T. (2012). Land grab' as development strategy? The political economy of agricultural investment in Ethiopia. Journal of Peasant Studies, 39(1), 37-41.

Likhitvidhayavuth, K. (2013). Cassava:Production and Marketing Situation. Office of Agricultural Economics. World Tapioca Conference, June 20. http://worldtapiocaconference.com/speaker/present/12.pdf Accessed, August 5, 2013.

Liu, P., Koroma, S., Arias, P., \& Hallam, D. (2013). Trends and Impacts of Foreign Investment in developing country agriculture. Evidence from Case Studies. Food and Organization of the United Nations, Rome.

Martinelli, L. A., Garrett, R., Ferraz, S., \& Naylor, R. (2011). Sugar and ethanol production as a rural development strategy in Brazil: Evidence from the state of Sao Paulo. Agricultural Systems, 104, 419-428.

Mhlanga, N., Blalock, G., \& Christy, R. (2010). Understanding foreign direct investment in the southern African development community: an analysis based on project-level data, Agricultural Economics $41: 337-347$.

Nweke, F. I., Spencer, D. S. C., \& Lynam, J. K. (2002). (Eds), The Cassava Transformation: Africa's Best Kept Secret. Michigan State University Press, East Lansing, MI.

OECD-FAO. (2015). Overview of theOECD-FAO Agricultural Outlook 2015-2024. http://www.fao.org/3/ai4738e.pdf. Accessed July 312016.

OECD. (2008). Organisation for Economic Co-operation and Development. Turning African Agriculture Into a Business: A Reader.

OECD. (2011a). Health at A Glance

OECD. (2011b). Revenue Administration in Sub-Saharan Africa, International Tax Dialogue (ITD), Comparative Study Series.

Ogundeinde, A., \& Ejohwomu, O. (2016). Knowledge Economy: A Panacea for Sustainable Development in Nigeria. Procedia Engineering, 145, 790-795.

Okudoh, V., Trois, C., Workneh, T., \& Schmidt, S. (2014). The potential of cassava biomass and applicable technologies for sustainable biogas production in South Africa: A review. Renewable and Sustainable Energy Reviews, 39, 1035-1052.

Oluwatoyese, O. P., Applanaidu, S. D. a. p., \& Razak, N. A. A. (2016). Macroeconomic Factors and Agricultural Sector in Nigeria. Procedia - Social and Behavioral Sciences, 219, 562-570.

Ongayo, A. O. (2008). Political instability in Africa Where the problem lies and alternative perspectives. The African Diaspora Policy Centre, Amsterdam. 
Oxfam. (2012). Our land, our lives; Time out on the global land rush. <https://www.oxfam.org/sites/www.oxfam.org/files/bn-land-lives-freeze-041012-en 1.pdf> Accessed 27 January, 2016.

Pelrine, R. J., Besigye, A., \& Schuster, R. (2010). The Role of Financial Services in Agribusiness Development: A Primer. USAID, 1st Edition

First.

Poole, N., Álvarez, F., Penagos, N., \& Vázquez, R. (2013). "Education for all and for what? Life - skills and livelihoods in rural communities", Journal of Agribusiness in Developing and Emerging Economies, Vol. 3 Iss: 1, pp.64 - 78.

Poole, N. D., Chitundu, M., \& Msoni, R. (2013). Commercialisation: A meta-approach for agricultural development among smallholder farmers in Africa? Food Policy, 41, 155-165.

Poramacom, N., Ungsuratana, A., Ungsuratana, P., \& Supavititpattana, P. (2013). Cassava production, prices and related policy in Thailand. Am. Int J Contemp Res; 3(5:)43-50.

Rada, N., \& Valdes, C. (2012). Policy, Technology and Efficiency of Brazilian Agriculture. United States Department of Agriculture. Economic Research Report, Number 137. http://www.ers.usda.gov/media/849055/err137.pdf Accessed June 5, 2013.

Rai, M., \& Ingle, A. (2012). Role of nanotechnology in agriculture with special reference to management of insect pests. Applied Microbiology and Biotechnology, 94, 287-293.

Reardon, T., \& Barrett, C. B. (2000). Agroindustrialization, globalization, and international development: An overview of issues, patterns, and determinants. Agricultural Economics, 23, 195-205.

Reardon, T., Barrett, C. B., Berdegue, J. A., \& Swinnen, J. F. M. (2009). Agrifood Industry Transformation and Small Farmers in Developing Countries. World Development, 37, 1717-1727.

Renwick, A., Islam, M. D., \& Thomson, S. (2012). Power in Global Agriculture: Economics, Politics, and Natural Resources. International Journal of Agricultural Management, Volume 2, Number 1, pp. 31-48(18).

Rottger, A. (2003). Strengthening farm-agribusiness linkages in Africa. Proceedings of Expert Consultation Nairobi, 23-27 March. Food and Agriculture Organization of the United Nations, Rome.

Rudi, L.M., Azadi, H., \& Witlox, F. (2012). Reconcilability of socio-economic development and environmental conservation in Sub-Saharan Africa. Global and Planetary Change, 86-87, 1- 10.

Schut, M., van Asten, P., Okafor, C., Hicintuka, C., Mapatano, S., Nabahungu, N. L., Kagabo, D., Muchunguzi, P., Njukwe, E., Dontsop-Nguezet, P. M., Sartas, M., \& Vanlauwe, B. (2016). Sustainable intensification of agricultural systems in the Central African Highlands: The need for institutional innovation. Agricultural Systems, 145, 165-176.

Schwab, K. (2013). The Global Competitiveness Report 2012-2013. World Economic Forum Geneva. http://www3.weforum.org/docs/WEF GlobalCompetitivenessReport 2012-13.pdf. Accessed June 5, 2013.

Seedhouse, A., Johnson, R., \& Newbery, R. (2016). Potholes and pitfalls: The impact of rural transport on female entrepreneurs in Nigeria. Journal of Transport Geography, 54, 140-147.

Shigaki, T. (2016). Cassava: The Nature and Uses. In Encyclopedia of Food and Health (pp. 687-693). Oxford: Academic Press.

Stock Market. (2013). Stimulating economic growth in Thailand cassava, June 25. http://www.stockmarkettodayblog.com/2013/06/25/stimulating-economic-growth-in-thailandcassava.html Accessed August 9, 2013.

Tersoo, P. (2013). Agribusiness as a Veritable Tool for Rural Development in Nigeria. Mediterranean Journal of Social Sciences 4,8. MCSER Publishing, Rome-Italy. 
TGP. (2007). Thai-German Partnership. Strengthening The Competitiveness and Eco-Efficiency of SMEs in Thailand. Market Assessment of Mechanization Potential for Cassava Production. AgriSource Co. Ltd. Thailand, March.

Toulmin, C. (2008). Securing land and property rights in sub-Saharan Africa: the role of local institutions. http://www.pubs.iied.org/pdfs/G00460.pdf

Toulmin, C. (2009). Securing land and property rights in sub-saharan Africa: The role of location institutions. Land Use Policy, 26, 10-19.

UNCTAD. (2008). World Investment Report 2008: Transnational Corporations and the Infrastructure Challenge (Geneva and New York: United Nations).

UNDESA. (2010). UN Department of Economic and Social Affairs, Population Division, World Population Prospects: The 2010 Revision.

UNDP. (1991). Human Development Report 1991. New York: Oxford University Press.

UNDP. (2013). Human Development Report. http://hdr.undp.org/hdr4press/press/report/index.html Accessed May 142013.

UNEP. (2005). -United Nations Environment Programme: Agriculture and economic development. UNEP and the International Bank of Reconstruction and Development/World Bank. Our Planet, the magazine of UNEP, Nairobi, Kenya.

UNESCO. (2010). The Current Status of Science around the World. UNESCO Science Report. http://unesdoc.unesco.org/images/0018/001899/189958e.pdf. Accessed 26 December 2012.

UNIDO. (2013). Agribusiness development-Transforming rural life to create wealth. http://www.unido.org/fileadmin/user media upgrade/What we do/Topics/Agribusiness and rural/RURAL web .pdf. Accessed May 7, 2013.

Voisard, J.-M., \& Jaeger, P. (2003). Ghana Horticulture Development Study, ESSD Africa, World Bank, Washington, D.C

Wagner Weick, C. (2001). Agribusiness technology in 2010: directions and challenges. Technology in Society, 23, 59-72.

WEF-B\&C-WB. (2013). Enabling Trade Valuing Growth Opportunties. World Economic Forum, Bain \& Company, The World Bank.

WEF-WB-AfDB. (2011). The Africa Competitiveness Report 2011.The World Economic Forum, The World Bank, and The African Development Bank.

Weinberger, K., \& Lumpkin, T. A. (2007). Diversification into Horticulture and Poverty Reduction: A Research Agenda. World Development, 35, 1464-1480.

WEO. (2010). The World Energy Outlook (WEO). Global status of modern energy access. http://www.worldenergyoutlook.org/resources/energydevelopment/globalstatusofmodernener gyaccess/Accessed 1 May 2013.

WHO. (2011). Global Health Observatory. Life Expectancy. http://www.who.int/gho/mortality burden disease/life tables/situation trends text/en/. Accessed 7 May 2013.

Wilkinson, J., \& Rocha, R. (2009). Agro-industry Trends, Patterns and Development Impacts, pp. 46 - 91, in: Da Silva, C.A., Baker, D., Shepherd, A.W., Jenane, C., \& Miranda-da-Cruz, S., 2009, FAO. CAB International.

Word Bank. (2009). Past Experience: Asia and Latin America vs. Sub-Saharan Africa,' in World Bank (2009) Awakening Africa's Sleeping Giant Prospects for Commercial Agriculture in the Guinea Savannah Zone and Beyond. Washington, DC

World Bank. (2008). World Development Report 2007: Agriculture for Development, Washington DC. World Bank. (2013). Growing Africa Unlocking the Potential of Agribusiness. The World Bank. Washington, DC. 
Yumkella, K. K., Kormawa, P. M., Reopstorff, T. M., \& Hawkins, A. M. (2011). Agribusiness for Africa's Prosperity. United Nations Industrial Development Organization (UNIDO). http://www.unido.org/fileadmin/user media/Services/AgroIndustries/Agribusiness for Africas Prosperity e-book NEW.pdf. Accessed 10 May, 2013.

Zhang, X., Rockmore, M., \& Chamberlin, J. (2007). A Typology for Vulnerability and Agriculture in SubSaharan Africa. IFPRI Discussion Paper 00734 


\begin{tabular}{|c|c|c|c|}
\hline Technologies & Advantages in agribusiness sector & Challenges & References \\
\hline $\begin{array}{l}\text { Biotechnology (e.g., marker } \\
\text { assisted selection, genetic } \\
\text { engineering) }\end{array}$ & $\begin{array}{l}\text { Better quality micronutrient Processing and digestibility } \\
\text { Improved yields and increased genetic diversity; variety of } \\
\text { crops } \\
\text { Drought tolerant varieties, pest and insect tolerant varieties } \\
\text { Shortened breeding cycle; more efficient breeding }\end{array}$ & $\begin{array}{l}\text { Environmental risk; gene flow, superweeds. } \\
\text { Health risk; toxicity and allergenicity fear of } \\
\text { domination by multinationals (e.g., Monsanto) } \\
\text { Weak biosafety system, } \\
\text { Intellectual property logjam }\end{array}$ & $\begin{array}{l}\text { (Adenle, Sowe, Parayil, \& } \\
\text { Aginam, 2012; Wagner } \\
\text { Weick, 2001) }\end{array}$ \\
\hline Nanotechnology & $\begin{array}{l}\text { Food manufacturing, food packaging and retailing - } \\
\text { nanosensors for monitoring sales and expiry dates } \\
\text { Nanomaterials-based pesticides and insecticides for pest } \\
\text { management, } \\
\text { Nanomaterials-biosensors for precision farming } \\
\text { Nanoparticle-based release of nutrients and water for crop } \\
\text { improvement }\end{array}$ & $\begin{array}{l}\text { Environmental hazard; nanomaterial may be } \\
\text { harmful to ecology } \\
\text { Health hazard; toxic nanomaterial ingestion in } \\
\text { food packaging }\end{array}$ & $\begin{array}{l}\text { (Chaudry, et al., 2008; } \\
\text { Kuzma \& VerHage, 2006; } \\
\text { Rai \& Ingle, 2012) }\end{array}$ \\
\hline $\begin{array}{l}\text { Information Communication } \\
\text { and Technology (e.g. mobile } \\
\text { phones, geographic } \\
\text { information system) }\end{array}$ & $\begin{array}{l}\text { Access to input and market information, } \\
\text { Reduce transaction costs for farmers and businesses } \\
\text { Yield and field monitoring } \\
\text { E-integrated pest management system E-extension }\end{array}$ & $\begin{array}{l}\text { Poor infrastructure; power failure, low } \\
\text { transmission signal, } \\
\text { Lack of ICT training } \\
\text { Lack of awareness, poverty and language } \\
\text { barriers }\end{array}$ & $\begin{array}{l}\text { (Adenle, et al., 2012; } \\
\text { African Economic } \\
\text { Outlook, 2009; Kiiza \& } \\
\text { Pederson, 2012) }\end{array}$ \\
\hline $\begin{array}{l}\text { Postharvest technology (e.g., } \\
\text { Ultraviolet, irradiation, small } \\
\text { scale metal silo) }\end{array}$ & $\begin{array}{l}\text { Less pesticide usage, } \\
\text { Aflatoxin mitigation, } \\
\text { Better quality of grains } \\
\text { Agroprocessing provides a boost to small-enterprise } \\
\text { development in the rural areas } \\
\text { Promoting small farmers incorporation into larger marketing } \\
\text { chains } \\
\text { Saving scarce land and water resources }\end{array}$ & $\begin{array}{l}\text { Inadequate infrastructure and capacity building } \\
\text { Poor maintenance culture, } \\
\text { Lack of skills and training }\end{array}$ & $\begin{array}{l}\text { (Kimatu, McConchie, } \\
\text { Xie, \& Nguluu, 2012; } \\
\text { Kitinoja, Saran, Roy, \& } \\
\text { Kader, 2011) }\end{array}$ \\
\hline $\begin{array}{l}\text { Renewable energy (e.g. } \\
\text { biofuel, biogas system, wind } \\
\text { energy) }\end{array}$ & $\begin{array}{l}\text { Conversion of manure, feeds and agricultural waste to } \\
\text { electricity for the village } \\
\text { Household food insecurity reduction } \\
\text { Local processing stimulates rural development and income } \\
\text { generation } \\
\text { Increase energy efficiency and contribute to environmental } \\
\text { sustainability }\end{array}$ & $\begin{array}{l}\text { Impact of biofuel on food security (e.g., } 1^{\text {st }} \\
\text { generation biofuel) } \\
\text { Limited technical capacity } \\
\text { Land tenure and weak regulatory framework }\end{array}$ & $\begin{array}{l}\text { (Demirbas, Balat, \& } \\
\text { Balat, 2009; Martinelli, } \\
\text { Garrett, Ferraz, \& Naylor, } \\
\text { 2011) }\end{array}$ \\
\hline
\end{tabular}


Table 2: Analysis of estimated demand for cassava in the domestic and foreign export market by the year 2015

\begin{tabular}{|c|c|c|c|c|}
\hline Value-added chain & $\begin{array}{c}\text { Estimated demand } \\
\text { (tonnes) }\end{array}$ & $\begin{array}{l}\text { Fresh root equivalent to meet } \\
\text { estimated demand (metric tons) }\end{array}$ & $\begin{array}{l}\text { Acreage required (25 } \\
\text { tonnes/ha) }\end{array}$ & $\begin{array}{c}\text { Number of job created (one } \\
\text { direct job on farm per ha and one } \\
\text { off-farm }\end{array}$ \\
\hline Starch & 230,000 & $1,1500,000$ & 46,000 & 92,000 \\
\hline Flour & 250,000 & $1,000,000$ & 40,400 & 80,000 \\
\hline *Sweeteners & 190,000 & 950,000 & 38,000 & 76,000 \\
\hline $\begin{array}{l}\text { Dried chips for export and animal } \\
\text { feed }\end{array}$ & 900,000 & $3,360,000$ & 134,400 & 268,560 \\
\hline$* *$ Fuel ethanol (E-10) & 0.5 billion litres & $3,571,428$ & 142,857 & 285,714 \\
\hline $\begin{array}{l}\text { High quality garri for export and } \\
\text { super market }\end{array}$ & 455,000 & $2,730,000$ & 109,200 & 218,400 \\
\hline Total & & $12,758,429$ & 510,337 & $1,020,674$ \\
\hline
\end{tabular}

6

$7 *$ Assumes $50 \%$ replacement of imported sugar in the sweetener industry

$8 * *$ Assumes $50 \%$ from cassava as feedstock

9 Source: Nigerian Ministry of Agriculture

10

11

12 
Table 3: Characteristics, agronomic practices and managements of cassava cultivation in Nigeria and Thailand

15

\begin{tabular}{|c|c|c|}
\hline & Nigeria & Thailand \\
\hline $\begin{array}{l}\text { Production system/ } \\
\text { Cassava area (hectare/farmer) }\end{array}$ & $\begin{array}{l}\text { Highly subsistent farming: } 0.2-0.3 \text { (smallholders, } \\
\text { labour intensive and low input, occasional use of } \\
\text { high yielding varieties }\end{array}$ & $\begin{array}{l}\text { Commercial mix: } 2-4 \text { (smallholders), } 4-16 \text { (medium farmers), } 20 \text { above } \\
\text { (large farmers), highly mechanized and regular use of high yield varieties }\end{array}$ \\
\hline Utilization & $\begin{array}{l}\text { Garri (70\%); Fufu (11\%); Animal feed (10\%); } \\
\text { Soft drink (5\%); Native starch (3\%); Others (1\%) }\end{array}$ & $\begin{array}{l}\text { Local consumption-modified/native starch (19\%), animal feed/citric acid } \\
\text { (13\%) Export market: pellets/chips (32\%), native/modified starch (36\%) }\end{array}$ \\
\hline Land preparation & Manual & Tractor (3+7disc) \\
\hline Planting/harvesting time & March-April (90\%)/Dec-July & April-May (70\%)/Dec-Aug \\
\hline $\begin{array}{l}\text { Crop system (\%) monocrop } \\
\text { Intercrop }\end{array}$ & $\begin{array}{l}10 \\
90\end{array}$ & $\begin{array}{ll}95 \\
5\end{array}$ \\
\hline Weed control & Hoe $1-2 x$ & Hoe 2-3x, small tractor/paraquat \\
\hline Harvest method & Hand & Hand/Tractor \\
\hline Main varieties & $\begin{array}{l}\text { TMS 90257, TMS84537, TMS82/00058, } \\
\text { TMS82/00661 }\end{array}$ & KU50, Rayong 5, Rayong 60, Rayong 90 \\
\hline $\begin{array}{l}\text { Fertilizer application } \\
\text { Organic (ton/hectare) } \\
\text { Inorganic }(\mathrm{kgN}+\mathrm{P} 2 \mathrm{O}+\mathrm{K} 2 \mathrm{O} / \text { hectare })\end{array}$ & $\begin{array}{l}\text { None } \\
\text { Very little }\end{array}$ & $\begin{array}{l}\text { medium } \\
30-120\end{array}$ \\
\hline $\begin{array}{l}\text { Production cost (US\$/ha) } \\
\text { Production cost (US } \$ / \text { fresh roots) } \\
\text { Labor cost (US } \$ \text { day) }\end{array}$ & $\begin{array}{l}680-900 \\
37.99 \\
3-4\end{array}$ & $\begin{array}{l}650-800 \\
28.68 \\
4-5\end{array}$ \\
\hline Processing technique & Traditional/manual & Highly efficient/sophisticated machine \\
\hline Yield (tons/hectare) & $8-12$ & $25-40$ \\
\hline
\end{tabular}

16

17 Source: (FAO, 2013b; Howeler, 2007; Howeler \& Hershey, 2001; Knipscheer, et al., 2007) 
Table 4: Possible role of government agencies in agribusiness and value chain development

20

\begin{tabular}{|c|c|}
\hline Government agencies & Possible role in agribusiness development \\
\hline $\begin{array}{l}\text { Ministry of } \\
\text { Agriculture }\end{array}$ & $\begin{array}{l}\text { 1) Intensify efforts to develop an integrative and functional framework in various aspect s of agribusiness sector } \\
\text { 2) Provide special farming training courses and extension services } \\
\text { 3) Create effective strategy for the adoption and distribution of improved technologies } \\
\text { 4) Oversee and coordinate state agriculture ministry's to adequately support and prioritize agribusiness development } \\
\text { 5) Identify constraints and risks to agribusiness development, and team up with the appropriate ministries in order to seek long lasting solution } \\
\text { 6) Support land acquisition and land governance that encourage agribusiness development } \\
\text { 7) Develop and coordinate effective marketing strategy with the Ministry of Trade and industry }\end{array}$ \\
\hline $\begin{array}{l}\text { Ministry of Trade and } \\
\text { industry }\end{array}$ & $\begin{array}{l}\text { 1) Improve bargaining power in international trade negotiations } \\
\text { 2) Stand to gain from bilateral partnerships through the best negotiation that is transparent and that favours national interest } \\
\text { 3) Coordinate data management systems with the National Statistics Office on formal and informal sector by targeting small-medium producers and } \\
\text { enterprises } \\
\text { 4) Promote an open trade policy for the regional and international integration of agribusiness } \\
\text { 5) Encourage local private sector and foreign sector partnership to enhance agribusiness development } \\
\text { 6) Collaborate and seek assistance from the United Nations Industrial Development Organization (UNIDO) and United Nations Conference on Trade and } \\
\text { Development (UNCTAD) on strategic path for trade development }\end{array}$ \\
\hline Ministry of Finance & $\begin{array}{l}\text { 1) Champion and finance agribusiness industry } \\
\text { 2) Encourage private agribusiness investment funds } \\
\text { 3) Coordinate and increase access to loans with the low interest rate from commercial banks } \\
\text { 4) Set up and monitor the performance of micro-credit and micro-finance } \\
\text { 5) Prioritize and channel financial resources towards agribusiness-supporting infrastructure with an international project lending institution such as World } \\
\text { Bank }\end{array}$ \\
\hline $\begin{array}{l}\text { Ministry of Science } \\
\text { and Technology }\end{array}$ & $\begin{array}{l}\text { 1) Champion research and development }(\mathrm{R} \& \mathrm{D}) \text { in agricultural technology } \\
\text { 2) Intensify R\&D in high yielding varieties and enrichment of germplasm banks in partnership with the Ministry of Agriculture and the United Nations of Food } \\
\text { and Agriculture Organizations (FAO) } \\
\text { 3) Promote appropriate indigenous technologies with the great potential for agribusiness and agricultural development (e.g., processing, storage) } \\
\text { 4) Coordinate and facilitate technology transfer } \\
\text { 5) Coordinate and support R\&D and capacity building across research institutes and universities at the national, regional and international levels }\end{array}$ \\
\hline Ministry of Power & $\begin{array}{l}\text { 1) Increase consistent provision of grid power that targets rural poor } \\
\text { 2) Establish open and transparent market conditions in partnership with the independent power producers or private sector } \\
\text { 3) Champion and encourage best available technologies in grid balancing and renewable energy integration (e.g. Solar, wind and hydropower) }\end{array}$ \\
\hline $\begin{array}{l}\text { Ministry of } \\
\text { Environment }\end{array}$ & $\begin{array}{l}\text { 1) Champion and develop sustainability best practices across agribusiness sectors } \\
\text { 2) Promote sustainable use of land, water, energy, forest and other key natural resources } \\
\text { 3) Establish and implement environmental policy guidelines for regulating pollutions } \\
\text { 4) Promote renewable energy policy for the overall energy mix that could help reduce greenhouse gases emissions }\end{array}$ \\
\hline Ministry of transport & $\begin{array}{l}\text { 1) Increase the participation of private sector in solving crucial infrastructure problems including roads, water and railways } \\
\text { 2) Coordinate and maintain effective logistic management of transport system } \\
\text { 3) Support and encourage the location of cultivating/processing plants to facilitate easy transportation }\end{array}$ \\
\hline
\end{tabular}




\begin{tabular}{|c|c|c|}
\hline National government & $\begin{array}{l}\text { 1) } \\
\text { 2) } \\
\text { 4) } \\
\text { 5) } \\
\text { 6) } \\
\text { 7) }\end{array}$ & $\begin{array}{l}\text { Create and implement policies targeting export-led industrialization with focus on agribusiness development } \\
\text { Emphasize the importance of private and public institution partnerships across all sectors of the economy } \\
\text { Review existing agribusiness policies and scale up to meet the current demands and implement appropriately } \\
\text { Champion the provision of essential infrastructures such as roads, railways, electric and water supply, and telecommunication system to attract foreign } \\
\text { investors } \\
\text { Provide funding through appropriate channels to local and state governments and set up targets } \\
\text { Improve trade policy, tariff system and other regulatory frameworks that target export trade } \\
\text { Invest in education and training, primary education and health }\end{array}$ \\
\hline State government & $\begin{array}{l}\text { 1) } \\
\text { 2) } \\
\text { 3) }\end{array}$ & $\begin{array}{l}\text { Build a strong relationship with all the relevant ministries, creating information platform for fostering agribusiness development } \\
\text { Identify specific areas that need attention and strengthen the communication between the local and national government } \\
\text { Should play a more active role in land procurement/utilization by agribusiness industries through a transparent and effective legislation }\end{array}$ \\
\hline Local government & 1) & $\begin{array}{l}\text { Encourage active participation of rural community in agribusiness development } \\
\text { Identify role of local enterprises in agribusiness development } \\
\text { Prioritize needs and communicate through the leaders to ensure inclusive decision-making at the national level. }\end{array}$ \\
\hline
\end{tabular}




\begin{tabular}{|c|c|c|c|c|}
\hline $\begin{array}{l}\text { Agricultural inputs } \\
\text { Top } 5 \text { foreign companies: } \\
\text { BASF } \\
\text { Dow Chemicals } \\
\text { Bayer } \\
\text { DuPont } \\
\text { Linde Group } \\
\text { Top } 5 \text { African companies: } \\
\text { SASOL } \\
\text { AECI } \\
\text { Omnia Holdings } \\
\text { Chemical Services } \\
\text { Industries } \\
\text { Chimiques du Sénégal }\end{array}$ & 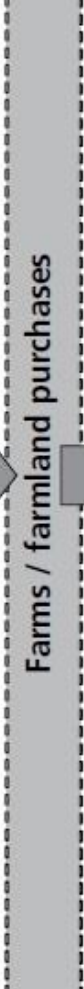 & $\begin{array}{l}\text { Food processors } \\
\text { Top } 3 \text { foreign companies: } \\
\text { Nestle } \\
\text { Unilever } \\
\text { Archer Daniels Midland } \\
\text { Top } 3 \text { African companies: } \\
\text { Tiger Brands } \\
\text { Tongaat-Hulett } \\
\text { AFGRI } \\
\text { Beverages } \\
\text { Top } 3 \text { foreign companies: } \\
\text { Coca Cola } \\
\text { InBev } \\
\text { Anheuser-Busch } \\
\text { Top } 3 \text { African companies: } \\
\text { SAB Miller } \\
\text { Distell Group } \\
\text { Nigerian Breweries } \\
\text { Tobacco } \\
\text { Top } 3 \text { foreign companies: } \\
\text { Altria Group } \\
\text { British American Tobacco } \\
\text { Japan Tobacco } \\
\text { Top } 3 \text { African companies: } \\
\text { Eastern Co. } \\
\text { BAT-Kenya } \\
\text { Sociéte Ivoirienne des Tabacs }\end{array}$ & $\begin{array}{l}\text { Food retailers / distributors } \\
\text { No foreign companies. } \\
\text { Top } 5 \text { African companies: } \\
\text { BidVest Group } \\
\text { Pick'n Pay Stores } \\
\text { Massmart Holdings } \\
\text { Shoprite Holdings } \\
\text { Spar Group } \\
\\
\text { Food services } \\
\text { Top } 3 \text { foreign companies: } \\
\text { Compass Group } \\
\text { McDonald's } \\
\text { Sodexo } \\
\text { Top } 3 \text { African companies:* } \\
\text { Anglovaal Industries } \\
\text { Astral Foods } \\
\text { Rainbow Chicken }\end{array}$ & 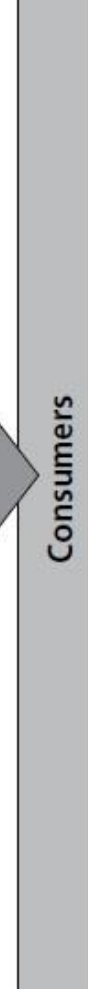 \\
\hline
\end{tabular}

27 Figure 1. The Sub-Saharan African agro-food supply chain: the existing large foreign and local 28 companies (Source: Mhlanga, 2010) 
Figure 2: Cassava production in Nigeria, Brazil and Thailand, 1990-2012

20000

10000
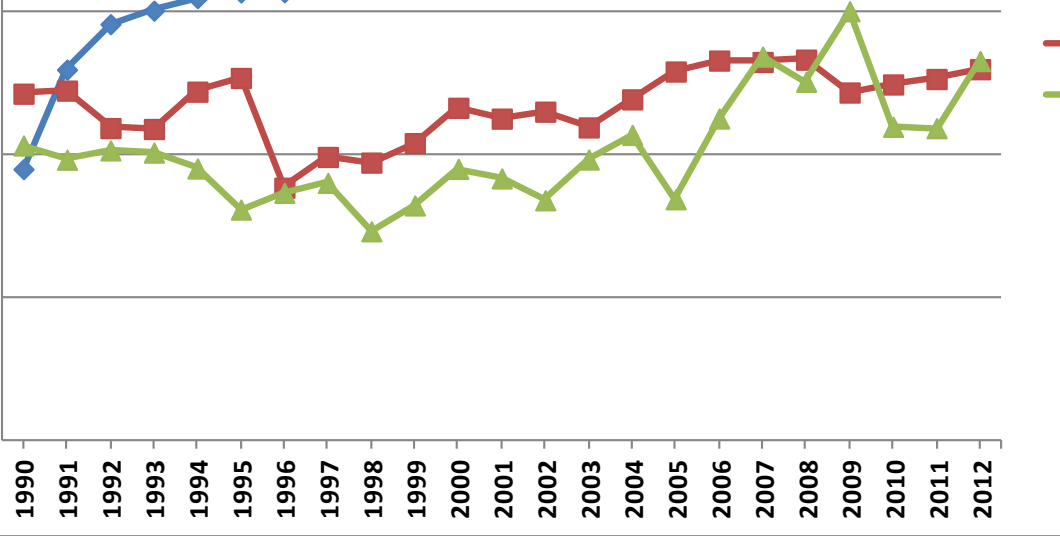


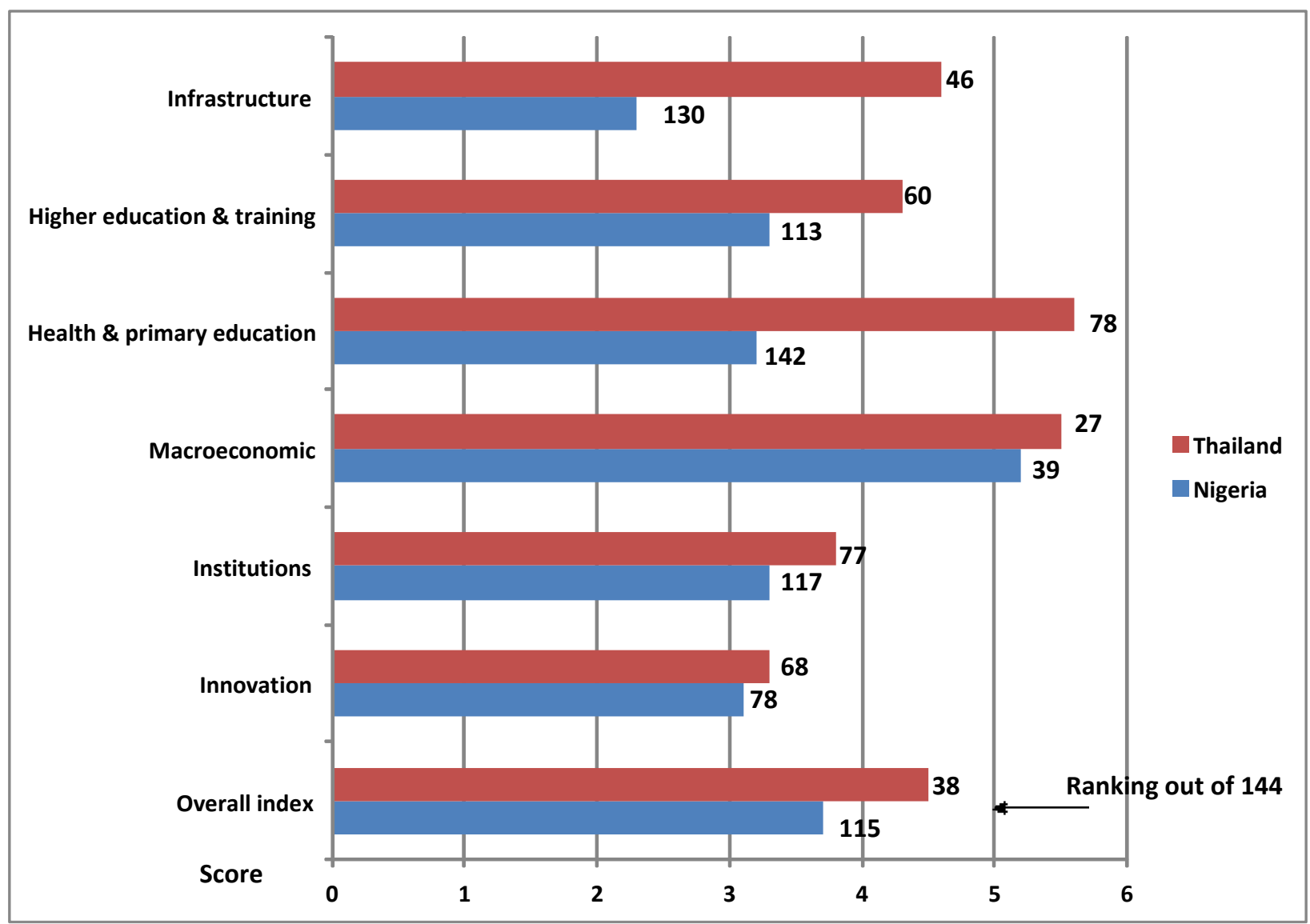

46 Figure 4: Six key cross-cutting pillars of global competitiveness in Nigeria and Thailand (higher 47 indicates greater competiveness based on scale 1-7, ranking among 144 countries)

48 Source: Authors' calculation based on data from World Economic Forum (Schwab, 2013) 

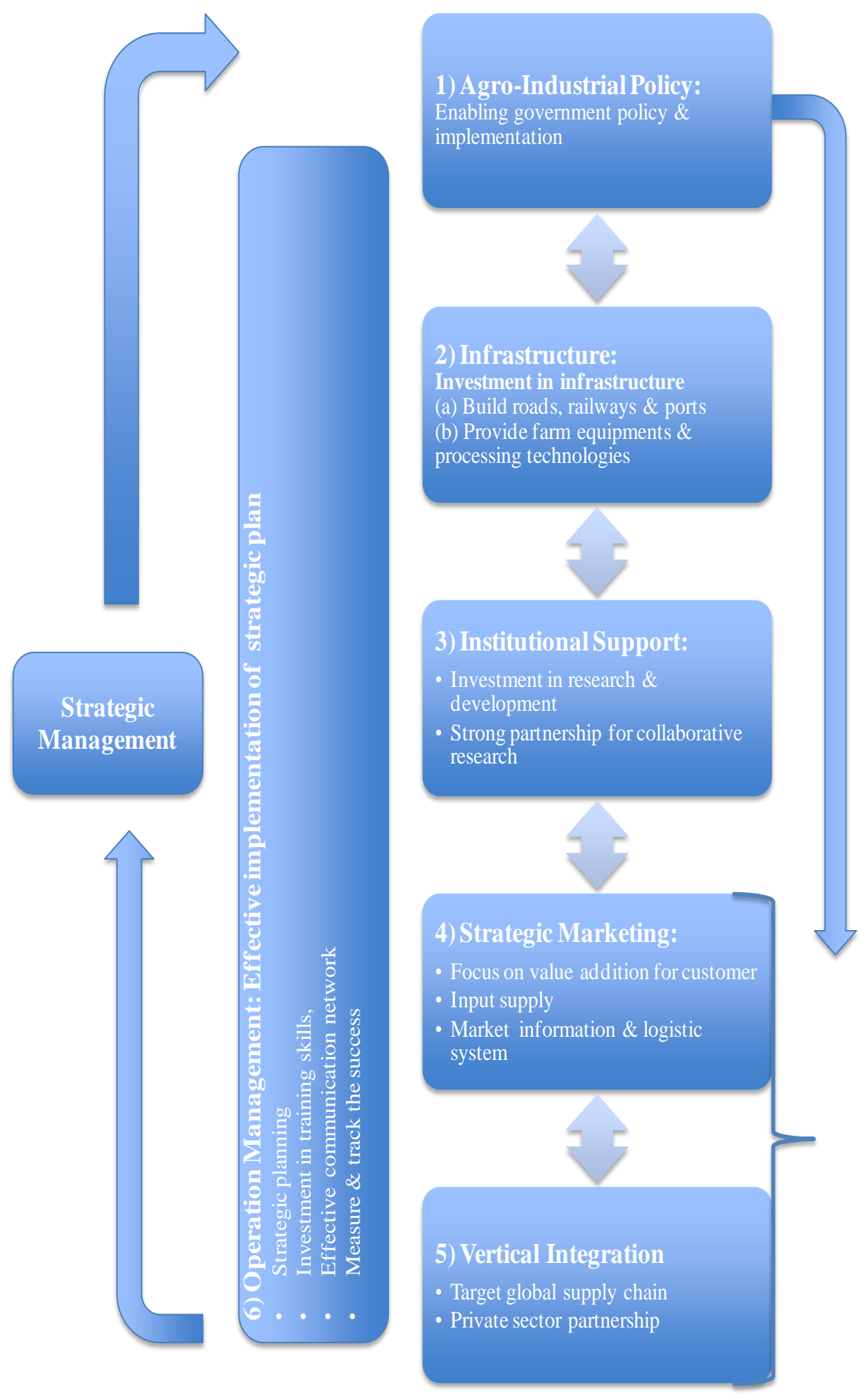

53 Figure 5: Strategic management approach to developing a cassava value chain in Nigeria. 
